\title{
Ornithobacterium rhinotracheale gen. nov., sp. nov., Isolated from the Avian Respiratory Tract
}

\author{
P. VANDAMME, ${ }^{1 *}$ P. SEGERS, ${ }^{1}$ M. VANCANNEYT, ${ }^{1}$ K. VAN HOVE, ${ }^{1}$ R. MUTTERS, ${ }^{2} \mathrm{~J}$ HOMMEZ, ${ }^{3}$ \\ F. DEWHIRST, ${ }^{4}$ B. PASTER,${ }^{4}$ K. KERSTERS,${ }^{1}$ E. FALSEN,${ }^{5}$ L. A. DEVRIESE, ${ }^{6}$ \\ M. BISGAARD, ${ }^{7}$ K.-H. HINZ, ${ }^{8}$ AND W. MANNHEIM ${ }^{2}$
}

Laboratorium voor Microbiologie, Faculteit Wetenschappen, ${ }^{1}$ and Laboratorium voor Bacteriologie, Faculteit Diergeneeskunde, ${ }^{6}$ University of Ghent, B-9000 Ghent, Belgium; Klinikum der Philipps-Universität Marburg, Marburg, Germany ${ }^{2}$; Provinciaal Verbond voor Dierenziektenbestrijding, Torhout, Belgium ${ }^{3}$; Department of Molecular Genetics, Forsyth Dental Center, Boston, Massachusetts 02115 ${ }^{4}$; Culture Collection, Department of Clinical Bacteriology, University of Göteborg, S-413 46 Göteborg, Sweden ${ }^{5}$; Royal Veterinary and Agricultural University and National Veterinary Laboratory, Frederiksberg, Denmark ${ }^{7}$; and Klinik für Geflügel der Tierärztlichen Hochschule, Hannover, Germany ${ }^{8}$

\begin{abstract}
The phylogenetic position and various genotypic, chemotaxonomic, and classical phenotypic characteristics of 21 gram-negative avian isolates were studied. These strains constitute a genotypically homogeneous taxon in rRNA superfamily V, as shown by DNA-rRNA hybridization data. Determination of the 16S rRNA sequence of this taxon revealed its detailed position within the "flavobacter" subgroup of the "flavobacter-bacteroides" phylum as described by Gherna and Woese (R. Gherna and C. R. Woese, Syst. Appl. Microbiol. 15:513-521, 1992). This new taxon is only distantly related to other members of the "flavobacter-bacteroides" phylum and is therefore given separate generic status. The DNA-DNA binding values for members of this taxon, for which we propose the name Ornithobacterium rhinotracheale, confirmed that all of the strains are highly interrelated (DNA-DNA binding values greater than $90 \%$ were measured). The $\mathrm{G}+\mathrm{C}$ contents of members of this taxon are between 37 and $39 \mathrm{~mol} \%$. An analysis of the cellular proteins and fatty acids and classical phenotypic characteristics allowed us to distinguish $O$. rhinotracheale from phenotypically similar taxa, such as Riemerella anatipestifer and Capnocytophaga species. The respiratory quinone content (menaquinone 7) and carbohydrate pattern of $O$. rhinotracheale conform with the respiratory quinone contents and carbohydrate patterns of other members of rRNA superfamily $V$.
\end{abstract}

In the past decade, we determined the protein and fatty acid profiles of a large number of avian isolates which could not be classified after primary identification tests were performed in veterinary laboratories. A total of 21 of these isolates had very similar profiles and differed clearly from all of the other strains investigated, including reference strains of well-known fowl pathogens. These 21 strains were isolated from the respiratory tracts of turkeys (10 strains), chickens ( 7 strains), rooks, ( 3 strains), and a partridge ( 1 strain). Clinical data were not available for all of these strains. However, most of the strains were associated with various respiratory tract infections, including tracheitis, pericarditis, sinusitis, airsacculitis, and pneumonia. Preliminary data on some of the chemotaxonomic characteristics of four strains have been described previously (36).

We studied a wide range of taxonomic parameters, including genotypic, chemotaxonomic, and classical phenotypic parameters, in order to establish the phylogenetic affiliation and to comprehensively describe the new taxon, for which we propose the name Ornithobacterium rhinotracheale. Special emphasis was given to the differentiation of $O$. rhinotracheale, Riemerella anatipestifer, and Capnocytophaga species as these taxa share a number of phenotypic characteristics.

\footnotetext{
* Corresponding author. Mailing address: Laboratorium voor Microbiologie, Universiteit Gent, K. L. Ledeganckstraat 35, B-9000 Gent, Belgium. Phone: 32-9-2645114. Fax: 32-9-2645346.
}

\section{MATERIALS AND METHODS}

Isolation of $\boldsymbol{O}$. rhinotracheale strains. Samples were inoculated onto media routinely used in veterinary laboratories, such as blood agar (e.g., Columbia agar base [catalog no. CM331; Oxoid] supplemented with 5 or $7 \%$ defibrinated sheep blood) or chocolate agar. The inoculated plates were incubated at different temperatures under various atmospheric conditions.

Bacterial strains and growth conditions. $O$. rhinotracheale strains and Riemerella and Capnocytophaga reference strains were grown on Trypticase soy agar (catalog no. 11768; BBL, Becton Dickinson Microbiology Systems, Cockeysville, Md.) and were incubated at 36 to $37^{\circ} \mathrm{C}$ in a microaerobic atmosphere containing approximately $5 \% \mathrm{O}_{2}$, $3.5 \% \mathrm{CO}_{2}, 7.5 \% \mathrm{H}_{2}$, and $84 \% \mathrm{~N}_{2}$ unless indicated otherwise. The strains used and their sources are shown in Table 1.

Bacteriological purity was checked by plating and examining living cells, using phase-contrast microscopy and Gram-stained cells. For mass cultures, cells were grown in Roux flasks.

PAGE of whole-cell proteins. $O$. rhinotracheale, Riemerella, and Capnocytophaga strains were grown for $48 \mathrm{~h}$ on one to three petri dishes. Whole-cell protein extracts were prepared, and sodium dodecyl sulfate (SDS)-polyacrylamide gel electrophoresis (PAGE) was performed as described previously (54).

Numerical analysis of the protein gel electropherograms. A densitometric analysis, normalization and interpolation of the protein profiles, and a numerical analysis were performed by using the GelCompar software package (Applied Maths, Kortrijk, Belgium) as described previously (45). 


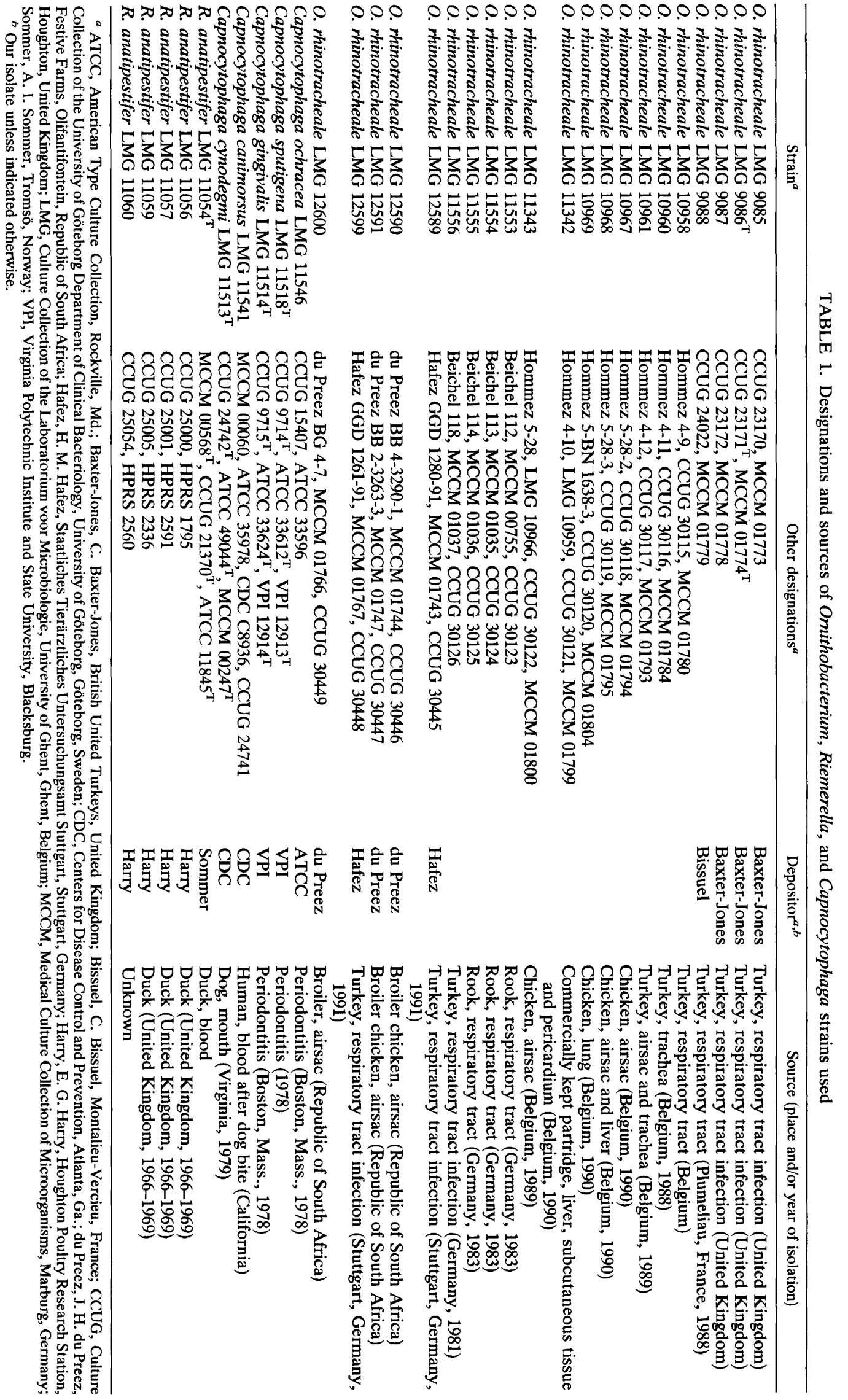




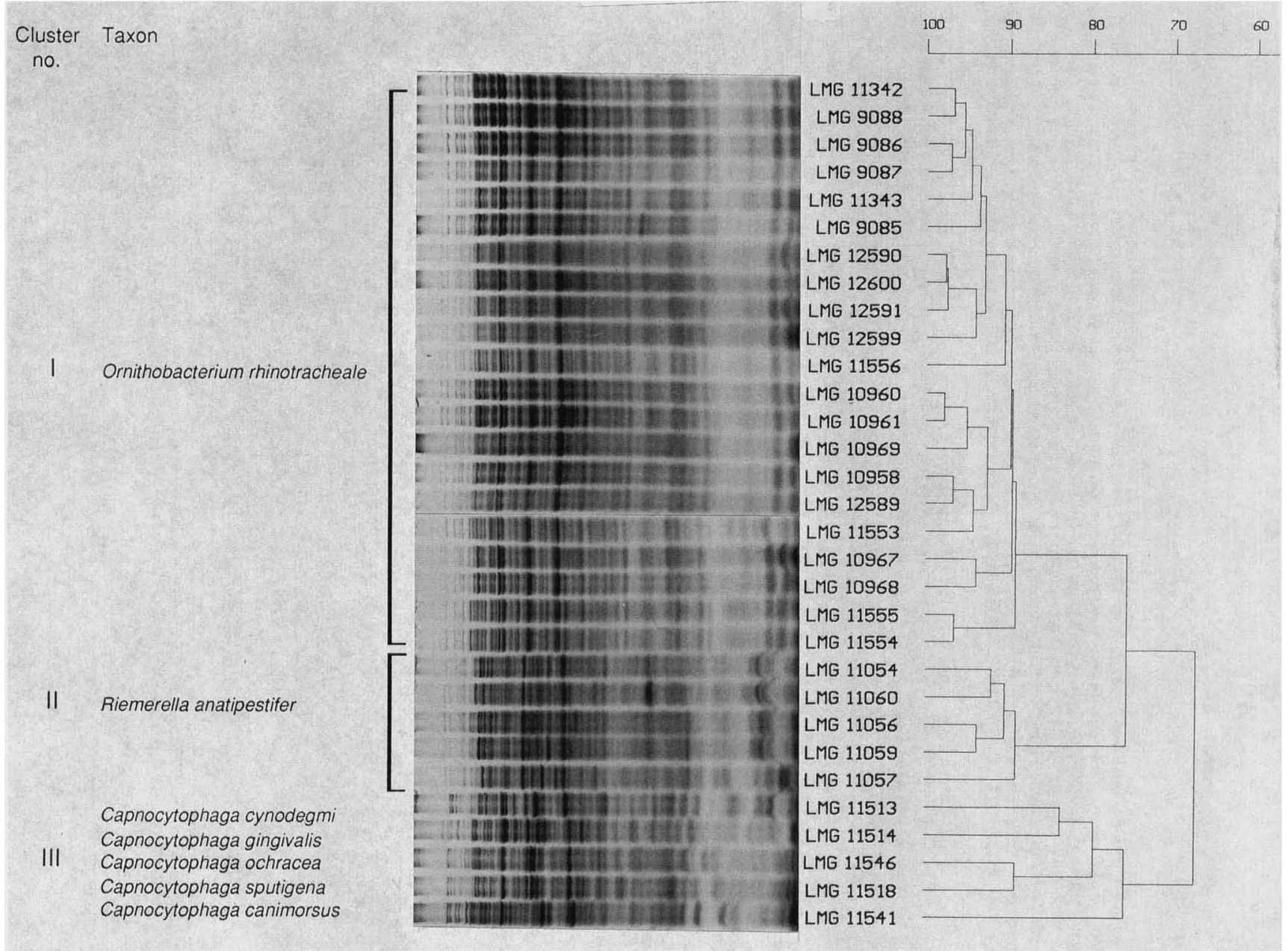

FIG. 1. Protein profiles of Ornithobacterium, Riemerella, and Capnocytophaga strains and corresponding dendrogram derived from unweighed pair group average linkage of correlation coefficients (expressed for convenience as percentages).

Fatty acid methyl ester analysis. After incubation for $48 \mathrm{~h}$, a loopful of well-grown cells was harvested, and fatty acid methyl esters were prepared, separated, and identified by using the Microbial Identification System (Microbial ID, Inc., Newark, Del.) as described previously (52).

Preparation of high-molecular-weight DNA. High-molecular-weight native DNA was prepared as described previously (52).

DNA base compositions. All of the $\mathrm{G}+\mathrm{C}$ contents were determined by the thermal denaturation method and were calculated by using the equation of Marmur and Doty (33), as modified by De Ley (10).

DNA-DNA hybridization experiments. The levels of DNADNA binding, expressed as percentages, were determined spectrophotometrically by using the initial renaturation rate method of De Ley et al. (12). Each value given below is the average of the values from at least two hybridization experiments. DNA binding values of $30 \%$ or less indicate that there was no significant DNA homology. The total DNA concentration was about $35 \mu \mathrm{g} / \mathrm{ml}$, and the optimal renaturation temperature in $2 \times \mathrm{SSC}(1 \times \mathrm{SSC}$ is $0.15 \mathrm{M} \mathrm{NaCl}$ plus $0.015 \mathrm{M}$ sodium citrate [pH 7]) was $66.4^{\circ} \mathrm{C}$.

DNA-rRNA hybridization experiments. In vivo radioactively labelled rRNA from $O$. rhinotracheale LMG $9086^{\mathrm{T}}$ (T $=$ type strain) was prepared by using a modification of the procedure of Aiba et al. (1). Bacterial cells were cultivated as described by De Ley and De Smedt (13). The cell growth from a $100-\mathrm{ml}$ broth culture (approximately $1 \mathrm{~g}$ ) was suspended in $9.5 \mathrm{ml}$ of buffer A containing $0.02 \mathrm{M}$ sodium acetate and 1 mM EDTA (pH 5.5). The cells were lysed by adding $0.5 \mathrm{ml}$ of $10 \%$ (wt/vol) SDS. After $10 \mathrm{ml}$ of phenol equilibrated in $0.02 \mathrm{M}$ sodium acetate $(\mathrm{pH} 5.5)$ was added, the mixture was incubated for $5 \mathrm{~min}$ at $60^{\circ} \mathrm{C}$ with gentle shaking. The solution was chilled on ice and centrifuged for $10 \mathrm{~min}$ at $10,000 \mathrm{rpm}$. The aqueous phase was reextracted with phenol, and the centrifugation step was repeated. The rRNA was precipitated by adding 2 to 3 volumes of cold $\left(-18^{\circ} \mathrm{C}\right)$ ethanol, centrifuged for $5 \mathrm{~min}$ at $5,000 \mathrm{rpm}$, and redissolved in $5 \mathrm{ml}$ of buffer $\mathrm{A}$. The ethanol precipitation step was repeated twice. Finally, the crude rRNA was dissolved in $1 \times$ SSC. All materials and solutions were autoclaved in a pressure cooker.

Radioactively labelled rRNAs from reference strains were obtained from members of the Ghent research group.

Purification of rRNA fractions, fixation of single-stranded DNA on membrane filters, chemical determination of the amount of DNA on a filter, saturation hybridization, RNase treatment, and measurements of the thermostabilities of the hybrids were performed as described by Van Landschoot and De Ley (53). Each DNA-rRNA hybrid was character- 
TABLE 2. Fatty acid compositions of the strains studied

\begin{tabular}{lccc}
\hline \multirow{3}{*}{ Fatty acid } & \multicolumn{3}{c}{$\%$ in $^{a}:$} \\
\cline { 2 - 4 } & $\begin{array}{c}\text { O. rhinotrache- } \\
\text { ale (21 strains) }\end{array}$ & $\begin{array}{c}R . \text { anatipestifer } \\
\text { (5 strains) }\end{array}$ & $\begin{array}{c}\text { Capnocyto- } \\
\text { phaga spp. } \\
\text { (5 strains) }\end{array}$ \\
\hline 13:0 iso & $\operatorname{Tr}(6)$ & $15.3 \pm 4.8(5)$ & $2.1 \pm 1.0(5)$ \\
ECL 13.566 & $4.2 \pm 1.5(21)$ & $1.2 \pm 0.4(5)$ & $1.9 \pm 0.4(5)$ \\
14:0 & $\operatorname{Tr}(15)$ & $\mathrm{ND}$ & $1.3 \pm 0.4(5)$ \\
15:0 iso & $57.4 \pm 6.1(21)$ & $52.2 \pm 2.5(5)$ & $67.4 \pm 2.6(5)$ \\
15:0 anteiso & $\operatorname{Tr}(7)$ & $5.6 \pm 1.4(5)$ & $1.5 \pm 0.4(5)$ \\
16:0 & $2.9 \pm 1.3(21)$ & $\operatorname{Tr}(2)$ & $2.2 \pm 0.4(5)$ \\
15:0 iso 3OH & $8.1 \pm 1.9(21)$ & $8.1 \pm 2.7(5)$ & $3.2 \pm 1.5(5)$ \\
ECL 16.580 & $1.1 \pm 0.5(18)$ & $\operatorname{Tr}(3)$ & $1.0 \pm 0.3(5)$ \\
17:0 iso & $1.5 \pm 1.0(19)$ & $\mathrm{ND}$ & $\operatorname{Tr}(3)$ \\
16:0 iso 3OH & $\mathrm{ND}$ & $1.1 \pm 0.7(5)$ & $\mathrm{ND}$ \\
16:0 3OH & $2.8 \pm 1.8(21)$ & $\operatorname{Tr}(3)$ & $4.6 \pm 1.3(5)$ \\
17:0 iso 3OH & $20.2 \pm 5.0(21)$ & $13.9 \pm 3.4(5)$ & $13.2 \pm 2.1(5)$ \\
\hline
\end{tabular}

$a$ The fatty acids for which the average amount for all three taxa was less than $1 \%$ are not given; therefore, the sum of the percentages for each group is not $100 \%$. Mean \pm standard deviation. The numbers in parentheses are the numbers of strains which contain the fatty acids. Tr, trace (less than $1 \%$ ); ND, not detected.

${ }^{b} \mathrm{ECL}$, equivalent chain length.

ized by the melting temperature of elution $\left[T_{m(e)}\right]$, the temperature at which $50 \%$ of the hybrid was denatured. A homologous duplex was a duplex formed between DNA and rRNA of the same strain; a heterologous hybrid was a duplex formed between DNA and rRNA of different strains. The higher the $T_{m(e)}$ of a heterologous hybrid, the more closely the two strains were related. The $T_{m(e)}$ values from reciprocal hybridization experiments in which all of the strains of each rRNA branch were used to calculate the average linkage level between each pair of rRNA branches.

16S rRNA sequencing. rRNA was isolated and partially purified by using a modification of the procedure of Pace et al. (40), as previously described (41). rRNA sequences were determined by using a modification of the standard Sanger dideoxy chain termination technique in which primers complementary to conserved regions were elongated with avian myeloblastosis virus reverse transcriptase (29). In addition to the standard primers (primers 2 through 5, 9, and 10 of Eaton et al. [17]), the following two primers were used: 5'-GGGGTTGCGCTCGTTATAGGACTT-3' (1093 reverse) and 5'-ACTAGCGATTCCAGCTTC-3' (1331 reverse).

Phylogenetic analysis of $16 \mathrm{~S}$ rRNA sequence information. The sequences were entered in the RNA program, a program designed for analysis of $16 \mathrm{~S}$ rRNA data and written in Microsoft QuickBASIC for use with IBM-PC-compatible computers, and were aligned as previously described (41). The data base contained approximately 250 sequences determined in our laboratory (B. P. and F. D.) and 200 sequences obtained from GenBank or from other researchers. Similarity matrices were constructed from aligned sequences by using only those base positions for which $90 \%$ of the strains had data. The similarity matrices were corrected for multiple base changes by the method of Jukes and Cantor (24). Phylogenetic trees were constructed by the neighborjoining method (44).

Phenotypic tests. A number of classical phenotypic tests and API ZYM tests were performed in three independent laboratories. Tests for the following characteristics were performed in the laboratory at Klinikum der Philipps-Universität Marburg, Marburg, Germany: motility; growth condition requirements (including medium, temperature, and
TABLE 3. DNA-DNA hybridization values for $O$. rhinotracheale strains

\begin{tabular}{ccccc}
\hline \multirow{2}{*}{ Strain } & \multicolumn{4}{c}{ \% of DNA binding to strain ${ }^{a}$ : } \\
\cline { 2 - 5 } & LMG 11556 & LMG 9086 $^{\mathrm{T}}$ & LMG 12590 & LMG 10960 \\
\hline LMG 11556 & 100 & & & \\
LMG 9086 & 93 & 100 & & \\
LMG 12590 & & 100 & 100 & \\
LMG 10960 & & 98 & 98 & 100 \\
\hline
\end{tabular}

${ }^{a}$ The values are the averages of the values from at least two hybridization experiments.

atmospheric requirements); cell and colony morphology; presence of oxidase, catalase (as described by Kilian [28]), alkaline phosphatase, arginine dihydrolase, lysine and ornithine decarboxylase, $\beta$-galactosidase ( $\alpha$-nitrophenyl- $\beta$-D-galactopyranoside test), and urease activities (as described by Lautrop [30]); growth on MacConkey agar, Endo agar, and Simmons citrate medium; reduction of nitrate; production of indole and hydrogen sulfide; hydrolysis of esculin; oxidation of ethanol; action on D-glucose in oxidation-fermentation medium; and acidification of wheat starch. All tests were performed as described by Mannheim et al. (32) unless indicated otherwise.

The following characteristics were examined in the laboratory at the Department of Clinical Bacteriology, University of Göteborg, Göteborg, Sweden, as described by De Vos et al. (14): cell and colony morphology; growth condition requirements (including medium, temperature, and atmospheric requirements); hemolysis and odor on horse blood agar; formation of pigment on nutrient agar; growth on Drigalski agar; motility; presence of oxidase, catalase, $\beta$-galactosidase ( $o$-nitrophenyl- $\beta$-D-galactopyranoside test), urease, lysine and ornithine decarboxylase, and arginine dihydrolase activities; formation of indole; reactions in triple sugar iron agar; reduction of nitrate and nitrite; denitrification; action on D-glucose in oxidation-fermentation medium; resistance to penicillin ( $10 \mu \mathrm{g}$ per disc); liquefaction of gelatin; requirement of $\mathrm{X}$ or $\mathrm{V}$ factor or porphyrin; and growth with D-galactose, D-glucose, lactose, D-mannitol, D-mannose, D-sorbitol, sucrose, and D-xylose as sole carbon sources.

Tests for the following characteristics were performed with $14 O$. rhinotracheale strains (they were not performed with strains LMG 11553, LMG 11554, LMG 11555, LMG 11556, LMG 12589, LMG 12590, and LMG 12591) in the laboratory at the Klinik für Geflügel der Tierärztlichen Hochschule, Hannover, Germany: motility; growth condition requirements; cell and colony morphology; presence of oxidase (26), catalase (27), lecithinase (on lecithinase agar [catalog no. SR47; Oxoid]), DNase (on DNase test agar [catalog no. 10449; Merck]), and urease (30) activities; growth on MacConkey agar (catalog no. 5465; Merck) and Drigalski agar (catalog no. 5316; Merck); esculin hydrolysis in esculin broth (catalog no. 3862; Merck); phenylalanine deaminase activity and use of malonate as a carbon source in malonate phenylalanine broth (catalog no. 5419; Merck); nitrate reduction in nitrate broth (catalog no. 10234; Merck); indole production in standard II nutrient broth (catalog no. 7884; Merck); $\beta$-galactosidase activity ( $O$-nitrophenyl- $\beta$-Dgalactopyranoside test); ornithine and lysine decarboxylase and arginine dihydrolase activities (34); gelatin hydrolysis (19); hyaluronidase (25) and chondroitin sulfatase (46) activities; production of acetylmethylcarbinol and the methyl red 
TABLE 4. $T_{m(e)}$ values for DNA-rRNA hybrids

\begin{tabular}{|c|c|c|c|c|c|c|}
\hline \multirow[b]{2}{*}{ Organism used for DNA isolation } & \multicolumn{6}{|c|}{$T_{m(e)}\left({ }^{\circ} \mathrm{C}\right)$ of hybrid with rRNA from: } \\
\hline & $\begin{array}{l}\text { O. rhinotracheale } \\
\text { LMG } 9086^{\mathrm{T}}\end{array}$ & $\begin{array}{c}\text { Capnocytophaga } \\
\text { ochracea LMG } \\
11546\end{array}$ & $\begin{array}{l}\text { R. anatipestifer } \\
{\text { LMG } 11054^{\mathrm{T}}}\end{array}$ & $\begin{array}{c}\text { Flavobacterium } \\
\text { aquatile LMG } \\
4008^{\mathrm{T}}\end{array}$ & $\begin{array}{c}\text { Flavobacterium } \\
\text { breve LMG } \\
4011^{\mathbf{T}}\end{array}$ & $\begin{array}{l}\text { Flavobacterium } \\
\text { indologenes } \\
\text { LMG } 8337^{\mathrm{T}}\end{array}$ \\
\hline O. rhinotracheale LMG 9085 & 76.8 & 63.7 & & & & \\
\hline O. rhinotracheale LMG $9086^{\mathrm{T}}$ & 75.9 & 62.9 & 66.5 & 63.3 & 65.9 & 64.7 \\
\hline O. rhinotracheale LMG 11553 & 76.1 & & & & & \\
\hline O. rhinotracheale LMG 11556 & 77.3 & & & & & \\
\hline Capnocytophaga ochracea LMG 11546 & 61.9 & 75.7 & 61.8 & 63.7 & 62.0 & 62.0 \\
\hline Capnocytophaga sputigena LMG $11518^{\mathrm{T}}$ & & 74.7 & & 68.4 & & \\
\hline Capnocytophaga gingivalis LMG $11514^{\mathrm{T}}$ & & 70.3 & & 66.3 & 61.2 & \\
\hline R. anatipestifer LMG $11054^{\mathrm{T}}$ & 67.2 & 64.5 & 77.5 & 65.0 & 64.5 & 72.4 \\
\hline R. anatipestifer LMG 11602 & 67.5 & & 77.6 & & 72.6 & 72.6 \\
\hline Flavobacterium aquatile LMG $4008^{\mathrm{T}}$ & 63.9 & 65.9 & & 77.0 & 64.7 & 63.5 \\
\hline Flavobacterium breve LMG $4011^{\mathrm{T}}$ & 65.0 & 63.9 & 64.0 & 64.6 & 76.4 & 63.9 \\
\hline Flavobacterium indologenes $\mathrm{LMG} 8337^{\mathrm{T}}$ & & 62.8 & 71.7 & 65.1 & 66.4 & 78.1 \\
\hline Flavobacterium meningosepticum LMG $12279^{\mathbf{T}}$ & 66.1 & 64.5 & 72.7 & 65.2 & 67.2 & 72.2 \\
\hline
\end{tabular}

test (7); and acid production from carbohydrates in phenol red broth base containing $1 \%$ carbohydrate with and without chicken serum.

API ZYM tests were performed in all three laboratories according to the recommendations of the manufacturer (bioMérieux, La Balme-les-Grottes, Montalieu-Vercieu, France).

The presence of the following enzymes or enzymatic activities was evaluated by using experimental API galleries (these characteristics were examined only by workers in the Department of Clinical Bacteriology, University of Göteborg, Göteborg, Sweden): production of acid from glucose, fructose, lactose, maltose, sucrose, D-glucosaminic acid (test not performed with strains LMG 12589, LMG 12590, LMG 12591, LMG 12599, and LMG 12600), D-saccharic acid (test not performed with strains LMG 12589, LMG 12590, LMG 12591, LMG 12599, and LMG 12600), dextrin, L-fucose (test not performed with strains LMG 12589, LMG 12590, LMG 12591, LMG 12599, and LMG 12600) galactose, $\mathrm{N}$-acetyl-glucosamine, lactulose, mannitol, mannose, ribose, sorbitol, trehalose, and xylose (test not performed with strains LMG 12589, LMG 12590, LMG 12591, LMG 12599, and LMG 12600); penicillinase; phenylalanine deaminase; alanine arylamidase; gamma-glutamyl arylamidase;

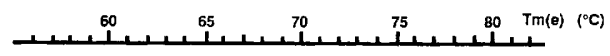

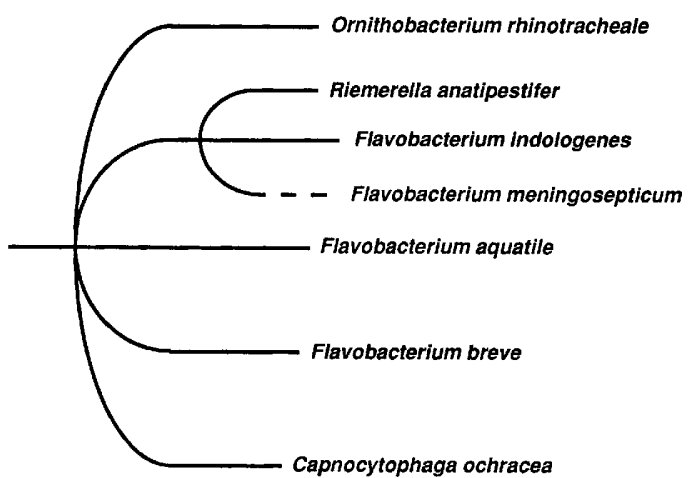

FIG. 2. Simplified rRNA cistron similarity dendrogram of part of rRNA superfamily $\mathrm{V}$. glycine arylamidase; hydroxyproline arylamidase; lysine arylamidase; proline arylamidase; pyroglutamic acid arylamidase; $\alpha$-glutamyl- $\alpha$-glutamic acid arylamidase; glycyl-phenylalanine arylamidase; phenylalanyl-arginine arylamidase; prolyl-arginine arylamidase; seryl-methionine arylamidase; 2-glycyl-glycyl-arginine arylamidase; alanyl-phenylalanylprolyl-alanine arylamidase; hippurate hydrolysis; phospholipase (test not performed with strains LMG 12589, LMG 12590, LMG 12591, LMG 12599, and LMG 12600); and phosphodiesterase.

Carbohydrate analysis. The cellular carbohydrates of all $O$. rhinotracheale strains except LMG 10958 and LMG 12590 were analyzed as described previously $(3,37)$. A loopful of well-grown cells was hydrolyzed in $2 \mathrm{~N}$ hydrochloric acid at $100^{\circ} \mathrm{C}$ for 20 min. Lipids were removed by hexane extraction, and the carbohydrates remaining in the dry residue of the aqueous phase were transformed to the corresponding peracetylated aldononitriles, peracetylated $o$-methyloximes, or alditol acetates. The peracetylated sugars were purified and subsequently analyzed by capillary gas chromatography and mass spectrometry.

\section{RESULTS}

Isolation of $O$. rhinotracheale strains. $O$. rhinotracheale can be isolated on common nonselective blood or chocolate agar media from samples obtained from the nasal cavity and infraorbital sinus, but large numbers of other bacteria may mask or overgrow the pinpoint colonies. However, in birds exhibiting pathological lesions of the lower respiratory tract, the organism can be found in pure culture in specimens from the trachea, lung, or airsac exudate. Inoculated plates should be incubated for at least $48 \mathrm{~h}$ at $37^{\circ} \mathrm{C}$ under microaerobic conditions (candle jar) or in air enriched with $10 \% \mathrm{CO}_{2}$; 2-day-old colonies are circular, small (approximately $1 \mathrm{~mm}$ in diameter), opaque to grayish, and butyrous.

PAGE of whole-cell proteins. Duplicate protein extracts of several strains were prepared to check the reproducibility of the growth conditions and the preparation of the extracts. The level of correlation between duplicate protein patterns was $\geq 0.95$.

Figure 1 shows the results of a numerical comparison of the protein profiles of all of the $O$. rhinotracheale, Capnocytophaga, and $R$. anatipestifer strains investigated. Cluster I contains all 21 isolates of $O$. rhinotracheale, which clus- 
TABLE 5. Organisms used for $16 \mathrm{~S}$ rRNA sequence comparisons and their culture collection numbers, nucleotide sequence accession numbers, and references

\begin{tabular}{|c|c|c|}
\hline Strain ${ }^{a}$ & $\begin{array}{c}\text { Nucleotide } \\
\text { sequence } \\
\text { accession } \\
\text { no. }{ }^{b}\end{array}$ & Reference \\
\hline $\begin{array}{l}\text { Ornithobacterium rhinotracheale LMG } \\
9_{9086^{\mathrm{T}}}\end{array}$ & L19156 & This study \\
\hline $\begin{array}{l}\text { Capnocytophaga canimorsus ATCC } \\
35979^{\mathrm{T}}\end{array}$ & L14637 & This study \\
\hline $\begin{array}{l}\text { Capnocytophaga cynodegmi ATCC } \\
49044^{\mathrm{T}}\left(=\mathrm{LMG} 11513^{\mathrm{T}}\right)\end{array}$ & L14638 & This study \\
\hline $\begin{array}{l}\text { Capnocytophaga gingivalis ATCC } 33624^{\mathrm{T}} \\
\quad\left(=\mathrm{LMG} 11514^{\mathrm{T}}\right)\end{array}$ & L14639 & This study \\
\hline $\begin{array}{l}\text { Capnocytophaga ochracea ATCC } 33596 \\
\text { (= LMG 11546) }\end{array}$ & L14635 & This study \\
\hline $\begin{array}{l}\text { Capnocytophaga sputigena ATCC } 33612^{\mathrm{T}} \\
\quad\left(=\mathrm{LMG} 11518^{\mathrm{T}}\right)\end{array}$ & L14636 & This study \\
\hline Cytophaga aquatilis ATCC $29551^{\mathrm{T}}$ & M58764 & 20 \\
\hline Cytophaga flevensis ATCC $27944^{\mathrm{T}}$ & M58767 & 20 \\
\hline Cytophaga johnsonae ATCC $17061^{\mathrm{T}}$ & M59051 & 20 \\
\hline Cytophaga johnsonae DSM 425 & M59053 & 20 \\
\hline Cytophaga latercula ATCC $23177^{\mathrm{T}}$ & M58769 & 20 \\
\hline Cytophaga lytica ATCC $23178^{\mathrm{T}}$ & M28058 & 58 \\
\hline Cytophaga marinoflava ATCC $19326^{\mathrm{T}}$ & M58770 & 20 \\
\hline Cytophaga uliginosa ATCC $14397^{\mathrm{T}}$ & M28238 & 58 \\
\hline Flavobacterium aquatile ATCC $11947^{\mathrm{T}}$ & M28236 & 58 \\
\hline Flavobacterium balustinum ATCC $33487^{\mathrm{T}}$ & M58771 & 20 \\
\hline Flavobacterium breve ATCC 14234 & M59052 & 20 \\
\hline Flavobacterium gleum ATCC $35910^{\mathrm{T}}$ & M58772 & 20 \\
\hline Flavobacterium gondwanese DSM 5423 & M92278 & 16 \\
\hline Flavobacterium indologenes ATCC $29897^{\mathrm{T}}$ & M58773 & 20 \\
\hline $\begin{array}{l}\text { Flavobacterium indoltheticum ATCC } \\
27950^{\mathrm{T}}\end{array}$ & M58774 & 20 \\
\hline $\begin{array}{l}\text { Flavobacterium meningosepticum ATCC } \\
13253^{\mathbf{T}}\end{array}$ & M58776 & 20 \\
\hline Flavobacterium odoratum ATCC $4651^{T}$ & M58777 & 20 \\
\hline Flavobacterium salegens DSM 5424 & M92279 & 16 \\
\hline Flectobacillus glomeratus ATCC $43844^{\mathrm{T}}$ & M58775 & 20 \\
\hline Flexibacter aurantiacus ATCC $31107^{\mathrm{T}}$ & M28054 & 58 \\
\hline Flexibacter aggregans ATCC $23162^{\mathrm{T}}$ & M58780 & 16 \\
\hline Flexibacter columnaris ATCC 43622 & M58781 & 20 \\
\hline Sporocytophaga cauliformis DSM 3657 & M93151 & 20 \\
\hline Vesiculata antartica ATCC 49675 & M61002 & 23 \\
\hline Weeksella virosa ATCC $43766^{\mathrm{T}}$ & M93152 & 20 \\
\hline Weeksella zoohelcum ATCC $43767^{\mathbf{T}}$ & M93153 & 20 \\
\hline
\end{tabular}

${ }^{a}$ Abbreviations: DSM, Deutsche Sammlung von Mikroorganismen und Zellkulturen $\mathrm{GmbH}$, Braunschweig, Germany; for other abbreviations, see Table 1, footnote $a$.

$b$ 16S rRNA sequences are available for electronic retrieval from the GenBank and EMBL data bases under the accession numbers indicated.

tered together at a similarity level of more than $89 \%$. Cluster II consists of five $R$. anatipestifer reference strains that clustered together at a similarity level of more than $89 \%$. Cluster III contains five Capnocytophaga reference strains, which clustered together at a similarity level of more than $76 \%$.

Fatty acid methyl ester composition. The average fatty acid methyl ester compositions of the $O$. rhinotracheale, Riemerella, and Capnocytophaga strains examined are shown in Table 2. Fatty acids 15:0 iso, 15:0 iso $3 \mathrm{OH}$, and 17:0 iso $3 \mathrm{OH}$ are the predominant fatty acids in all of the strains studied. The high percentages of $17: 0$ iso $3 \mathrm{OH}$ and an unidentified fatty acid with an equivalent chain length of 13.566 differentiate $O$. rhinotracheale from Capnocytophaga spp. and $R$. anatipestifer. The latter taxon is characterized by two addi- tional fatty acids, 13:0 iso and 15:0 anteiso, which are present to much lesser extents in the other taxa. Additional characteristics that differentiate Capnocytophaga spp. from the other taxa are the relatively low percentage of 15:0 iso $3 \mathrm{OH}$ and the relatively high percentage of $16: 03 \mathrm{OH}$. As shown by the small standard deviations, no significant differences were noted among the reference strains of the five Capnocytophaga species (data not shown).

DNA base compositions. Four $O$. rhinotracheale strains (LMG 9085, LMG 9086 ${ }^{\mathrm{T}}$, LMG 11553, and LMG 11556) were selected at random to determine DNA base ratios; the base compositions of these strains were $39,38,37$, and 38 $\mathrm{mol} \% \mathrm{G}+\mathrm{C}$, respectively.

DNA-DNA hybridization results. Four $O$. rhinotracheale strains (LMG 9086 ${ }^{\mathrm{T}}$, LMG 10960, LMG 11556, and LMG 12590) were selected at random for DNA-DNA hybridization experiments. DNA binding values greater than $93 \%$ were obtained (Table 3).

DNA-rRNA hybridization results. The DNA-rRNA hybridization results are shown in Table 4 (all values for crossreactions between reference strains will be published elsewhere [45]) and are presented as a simplified dendrogram based on the $T_{m(e)}$ values of the hybrids in Fig. 2. The position of $O$. rhinotracheale within the FlavobacteriumCytophaga rRNA complex (rRNA superfamily V) is shown in Fig. 2. The average $T_{m(e)}$ values obtained from about 80 reciprocal hybridizations between strains belonging to different rRNA branches were used to calculate the average linkage level between each pair of rRNA branches (Table 4) (45). This linkage level is at an average $T_{m(e)}$ of $65.1 \pm 1.5^{\circ} \mathrm{C}$. The detailed structure of rRNA superfamily $\mathrm{V}$ is discussed elsewhere (45). The genera Capnocytophaga and Riemerella occupy separate positions and branch off at the same base level.

16S rRNA sequence analysis. The $16 \mathrm{~S}$ rRNA sequences of O. rhinotracheale LMG $9086^{\mathrm{T}}$ and five Capnocytophaga species have been deposited in the GenBank data base and are available for electronic retrieval under the accession numbers shown in Table 5. The accession numbers of additional reference organisms included in the 16S rRNA phylogenetic analysis are also shown in Table 5.

The results of a comparison between the 16S rRNA sequence of strain LMG $9086^{\mathrm{T}}$ and the sequences of 31 reference species are shown in Table 6 . The matrix is based on comparisons at 1,422 base positions for which more than $90 \%$ of the strains had data. The lower half of the matrix is expressed as percentages of differences corrected for multiple base changes by the method of Jukes and Cantor (24). A phylogenetic tree determined from the corrected matrix by using the neighbor-joining method is shown in Fig. 3. Species representing the Cytophaga and "flavobacter" subgroups of the "flavobacter-bacteroides" phylum are shown.

Phenotypic analysis. The results of classical phenotypic tests and reactions in API ZYM galleries were determined for only $O$. rhinotracheale strains. Similar results were found for nearly all of the tests performed in three independent laboratories, regardless of the method used; however, a number of discrepancies were observed. All of the strains exhibited urease activity if the Lautrop nonproliferative test (30) was used, whereas only 13 of 21 strains produced urease in Christensen medium without agar. All strains produced oxidase activity when the method of Mannheim et al. (32) and Kersters and De Ley (26) was used, whereas only 15 of 21 strains produced oxidase when the Pathotec system was used and only 17 of 21 strains produced oxidase when 
TABLE 6. Similarity matrix based on $16 \mathrm{~S}$ rRNA sequence comparisons

\begin{tabular}{|c|c|c|c|c|c|c|c|c|c|c|c|c|c|}
\hline & \multicolumn{13}{|c|}{$\%$ Similarity and \% difference compared with ${ }^{\mathrm{a}}$ : } \\
\hline & Orh & Fme & $W_{z o}$ & $F g l$ & Fig & Fin & $\mathrm{Fba}$ & $\mathrm{Fbr}$ & $W v i$ & $\mathrm{Coc}$ & Csp & Cay & Cca \\
\hline Ornithobacterium rhinotracheale & - & 89.9 & 86.6 & 86.9 & 86.9 & 87.4 & 87.7 & 89.9 & 88.1 & 84.8 & 84.2 & 84.2 & 84.1 \\
\hline Flavobacterium meningosepticum & 10.8 & - & 92.6 & 94.2 & 94.2 & 94.3 & 93.9 & 91.4 & 89.6 & 85.6 & 85.0 & 86.2 & 85.9 \\
\hline Weeksella zoohelcum & 14.8 & 7.8 & - & 95.2 & 94.9 & 92.8 & 93.1 & 86.6 & 86.4 & 83.2 & 82.4 & 83.7 & 84.1 \\
\hline Flovobacterium gleum & 14.5 & 6.0 & 5.0 & - & 98.9 & 95.6 & 96.1 & 87.2 & 87.1 & 83.0 & 81.9 & 84.1 & 84.0 \\
\hline Flavobacterium indologenes & 14.4 & 6.1 & 5.3 & 1.1 & - & 95.4 & 96.3 & 87.1 & 87.2 & 83.1 & 82.0 & 84.5 & 84.1 \\
\hline Flavobacterium indoltheticum & 13.8 & 5.9 & 7.6 & 4.5 & 4.8 & - & 97.6 & 87.3 & 87.6 & 82.6 & 81.6 & 83.7 & 83.7 \\
\hline Flavobacterium balustinum & 13.4 & 6.3 & 7.2 & 4.1 & 3.8 & 2.5 & - & 88.0 & 87.6 & 82.4 & 81.5 & 83.5 & 83.4 \\
\hline Flavobacterium breve & 10.9 & 9.1 & 14.7 & 14.1 & 14.2 & 13.9 & 13.1 & - & 92.8 & 84.7 & 84.2 & 85.2 & 85.2 \\
\hline Weeksella virosa & 13.0 & 11.2 & 15.0 & 14.2 & 14.0 & 13.6 & 13.6 & 7.6 & $\ldots$ & 84.9 & 83.7 & 84.9 & 84.8 \\
\hline Capnocytophaga ochracea & 17.0 & 15.9 & 19.0 & 19.3 & 19.1 & 19.9 & 20.0 & 17.1 & 16.8 & - & 96.4 & 93.2 & 92.6 \\
\hline Capnocytophaga sputigena & 17.7 & 16.8 & 20.0 & 20.8 & 20.5 & 21.2 & 21.2 & 17.8 & 18.4 & 3.7 & - & 93.3 & 92.4 \\
\hline Capnocytophaga cynodegmi & 17.7 & 15.2 & 18.4 & 17.9 & 17.4 & 18.4 & 18.6 & 16.4 & 16.9 & 7.1 & 7.1 & - & 98.6 \\
\hline Capnocytophaga canimorus & 17.8 & 15.7 & 17.9 & 18.0 & 17.9 & 18.4 & 18.8 & 16.5 & 16.9 & 7.8 & 8.0 & 1.4 & - \\
\hline Capnocytophaga gingivalis & 16.6 & 16.2 & 18.4 & 18.5 & 18.2 & 19.6 & 19.3 & 17.7 & 18.0 & 8.9 & 8.8 & 8.4 & 8.9 \\
\hline Cytophaga uliginosa & 18.1 & 17.6 & 18.7 & 20.7 & 20.5 & 21.3 & 20.9 & 18.1 & 18.5 & 14.9 & 15.6 & 14.4 & 14.1 \\
\hline Cytophaga lytica & 18.2 & 16.1 & 19.2 & 20.6 & 20.0 & 19.5 & 20.1 & 16.3 & 17.7 & 13.5 & 13.7 & 12.9 & 12.1 \\
\hline Cytophaga marinoflava & 16.3 & 15.9 & 18.2 & 19.7 & 19.8 & 20.3 & 20.4 & 16.3 & 17.4 & 14.0 & 15.4 & 14.7 & 14.3 \\
\hline Cytophaga latercula & 17.8 & 16.3 & 19.9 & 18.8 & 18.9 & 18.0 & 18.7 & 16.1 & 16.3 & 14.2 & 15.2 & 13.0 & 12.6 \\
\hline Flavobacterium gondwanense & 16.7 & 16.5 & 19.9 & 21.3 & 21.0 & 20.5 & 20.5 & 16.5 & 17.8 & 14.9 & 16.0 & 14.3 & 13.9 \\
\hline Flavobacterium salegens & 17.8 & 17.2 & 20.2 & 21.5 & 21.5 & 20.6 & 20.8 & 17.3 & 17.8 & 15.6 & 16.7 & 16.0 & 15.3 \\
\hline Flectobacillus glomeratus & 17.4 & 16.6 & 18.7 & 19.5 & 19.3 & 18.4 & 18.2 & 17.4 & 16.8 & 15.7 & 16.1 & 15.9 & 14.8 \\
\hline Vesiculata antarctica & 16.7 & 15.6 & 18.8 & 19.6 & 19.7 & 17.9 & 17.9 & 16.7 & 17.2 & 15.9 & 16.3 & 16.4 & 15.4 \\
\hline Flexibacter aggregans & 17.6 & 15.7 & 19.3 & 19.5 & 19.3 & 19.3 & 18.8 & 18.1 & 17.7 & 15.6 & 16.0 & 15.2 & 14.2 \\
\hline Flavobacterium odoratum & 15.9 & 14.8 & 18.7 & 18.1 & 18.0 & 17.9 & 16.8 & 15.2 & 14.5 & 14.4 & 15.1 & 14.7 & 14.6 \\
\hline Flavobacterium aquatile & 15.0 & 15.4 & 18.9 & 18.6 & 18.8 & 17.1 & 17.3 & 14.8 & 15.6 & 13.2 & 13.6 & 12.4 & 11.9 \\
\hline Cytophaga johnsonae ATCC $17061^{\mathrm{T}}$ & 16.6 & 15.7 & 19.4 & 18.3 & 18.3 & 18.6 & 18.3 & 14.6 & 15.0 & 13.2 & 12.6 & 11.0 & 10.9 \\
\hline Flexibacter aurantiacus & 16.8 & 15.8 & 19.6 & 18.6 & 18.5 & 18.7 & 18.3 & 14.8 & 15.3 & 13.6 & 12.9 & 11.1 & 11.0 \\
\hline Cytophaga flevensis A-34 & 16.4 & 16.2 & 18.3 & 17.5 & 17.5 & 17.7 & 17.1 & 14.9 & 15.8 & 12.8 & 12.6 & 10.1 & 10.0 \\
\hline Cytophaga aquatilis & 16.6 & 16.2 & 19.5 & 18.6 & 18.4 & 18.4 & 17.7 & 14.9 & 15.7 & 13.4 & 13.2 & 11.6 & 11.0 \\
\hline Flexibacter columnaris & 16.8 & 16.2 & 19.5 & 19.2 & 18.8 & 19.1 & 18.0 & 14.7 & 15.5 & 13.3 & 13.1 & 11.8 & 11.5 \\
\hline Cytophaga johnsonae DSM 425 & 16.4 & 15.9 & 19.6 & 19.4 & 19.6 & 18.3 & 18.0 & 14.4 & 15.8 & 12.9 & 12.6 & 11.8 & 11.6 \\
\hline Sporocytophaga cauliformis & 16.7 & 16.2 & 19.9 & 19.3 & 19.4 & 18.4 & 18.1 & 14.4 & 15.3 & 13.2 & 13.2 & 11.9 & 11.8 \\
\hline
\end{tabular}

${ }^{a}$ The numbers on the upper right are uncorrected levels of similarity; the numbers on the lower left are levels of difference corrected for multiple base changes by the method of Jukes and Cantor. Abbreviations: Orh, Ornithobacterium rhinotracheale; Fme, Flavobacterium meningosepticum; Wzo, Weeksella zoohelcum; Fgl, Flavobacterium gleum; Fig, Flavobacterium indologenes; Fin, Flavobacterium indoltheticum; Fba, Flavobacterium balustinum; Fbr, Flavobacterium breve; Wvi, Weeksella virosa; Coc, Capnocytophaga ochracea; Csp, Capnocytophaga sputigena; Ccy, Capnocytophaga cynodegmi; Cca, Capnocytophaga canimorsus; Cgi, Capnocytophaga gingivalis; Cul, Cytophaga uliginosa; Cly, Cytophaga lytica; Cma, Cytophaga marinoflava; Cla, Cytophaga latercula; Gfp, Flavobacterium gondwanense; Fsa, Flavobacterium salegens; Fgl, Flectobacillus glomeratus; Van, Vesiculata antarctica; Fag, Flexibacter aggregans; Fod, Flavobacterium odoratum; Faq, Flavobacterium aquatile; Cj1, Cytophaga johnsonae ATCC 17061 ${ }^{\mathrm{T}}$; Fau, Flexibacter aurantiacus; Cfl, Cytophaga flevensis A-34; Caq, Cytophaga aquatilis; Fco, Flexibacter columnaris; Cj2, Cytophaga johnsonae DSM 425; Sca, Sporocytophaga cauliformis.

Kovacs' reagent (31) was used. Testing for arginine dihydrolase activity by using a heavy inoculum in Möller's medium yielded 19 positive reactions after 3 days of incubation at $36^{\circ} \mathrm{C}$ (strains LMG 10958 and LMG 11555 did not react). The results obtained with the API ZYM galleries were reproducible only when a heavy inoculum was used. Differences in test results among the three laboratories were found only for the following tests which yielded strain-dependent results (although all strains exhibited at least weak activity): esterase $\mathrm{C} 4$, valine arylamidase, cysteine arylamidase, tryp$\sin$, and $\alpha$ - and $\beta$-galactosidase. Strain-dependent results were recorded in all three laboratories for chymotrypsin activity. The results of the remaining classical and API ZYM tests are described below in the description of the new taxon.

Enzymes belonging to the experimental galleries were tested for $O$. rhinotracheale strains and for five Capnocytophaga and $R$. anatipestifer reference strains (Table 1). The following activities were present in all strains: alanine arylamidase; glycine arylamidase; lysine arylamidase; proline arylamidase; $\alpha$-glutamyl- $\alpha$-glutamic acid arylamidase; glycyl-phenylalanine arylamidase; phenylalanyl-arginine arylamidase; prolyl-arginine arylamidase; seryl-methionine arylamidase; 2-glycyl-glycyl-arginine arylamidase; and alanyl-phenylalanyl-prolyl-alanine arylamidase. The following characteristics were negative for all strains: production of acid from D-glucosaminic acid, D-saccharic acid, L-fucose, mannitol, sorbitol, trehalose, and xylose; phenylalanine deaminase activity; hippurate hydrolysis; and phospholipase activity. All of the other test results are shown in Table 7. When the API galleries were used, $O$. rhinotracheale LMG $9086^{\mathbf{T}}$ did not produce acid from glucose, fructose, maltose, sucrose, or dextrin (Table 7), whereas acid production was observed for the same strain in phenol red broth base containing $1 \%$ carbohydrate with and without chicken serum. The latter reaction pattern is more in agreement with the general profile of this species (Table 7).

Carbohydrate profiles. All of the strains except LMG 9087 contained high amounts of lyxose (up to $30 \%$ ). Mannose, glucose (except LMG 11554), and galactose were always present; altrose, sorbose, and heptoses were always absent. Ribose was present in most strains. The detailed carbohy- 
TABLE 6-Continued

\begin{tabular}{|c|c|c|c|c|c|c|c|c|c|c|c|c|c|c|c|c|c|c|}
\hline \multicolumn{19}{|c|}{$\%$ Similarity and $\%$ difference compared with": } \\
\hline$C g i$ & $\mathrm{Cul}$ & Cly & $C m a$ & Cla & Gfp & Fsa & $\mathrm{Fgl}$ & Van & Fag & Fod & Faq & Cj1 & $F a u$ & $C f$ & Caq & FCO & $C j 2$ & $S c a$ \\
\hline 85.1 & 83.9 & 83.8 & 85.4 & 84.2 & 85.0 & 84.2 & 84.5 & 85.1 & 84.3 & 85.6 & 86.4 & 85.1 & 85.0 & 85.2 & 85.1 & 84.9 & 85.3 & $\overline{85.1}$ \\
\hline 85.5 & 84.3 & 85.5 & 85.7 & 85.3 & 85.2 & 84.6 & 85.1 & 85.9 & 85.9 & 86.5 & 86.1 & 85.8 & 85.7 & 85.4 & 85.4 & 85.4 & 85.7 & 85.4 \\
\hline 83.6 & 83.4 & 83.1 & 83.9 & 82.6 & 82.5 & 82.3 & 83.4 & 83.3 & 83.0 & 83.4 & 83.3 & 82.9 & 82.8 & 83.7 & 82.8 & 82.9 & 82.8 & 82.5 \\
\hline 83.6 & 81.9 & 82.0 & 82.7 & 83.4 & 81.4 & 81.3 & 82.8 & 82.7 & 82.9 & 83.9 & 83.5 & 83.7 & 83.5 & 84.4 & 83.5 & 83.0 & 82.9 & 83.0 \\
\hline 83.8 & 82.1 & 82.4 & 82.6 & 83.3 & 81.7 & 81.3 & 83.0 & 82.7 & 83.0 & 84.0 & 83.4 & 83.8 & 83.6 & 84.4 & 83.7 & 83.4 & 82.8 & 82.9 \\
\hline 82.8 & 81.5 & 82.8 & 82.2 & 84.0 & 82.1 & 82.0 & 83.7 & 84.1 & 83.0 & 84.1 & 84.7 & 83.5 & 83.5 & 84.3 & 83.7 & 83.1 & 83.8 & 83.7 \\
\hline 83.0 & 81.7 & 82.4 & 82.1 & 83.5 & 82.1 & 81.8 & 83.8 & 84.1 & 83.3 & 85.0 & 84.6 & 83.8 & 83.8 & 84.7 & 84.3 & 84.0 & 84.0 & 83.9 \\
\hline 84.2 & 83.9 & 85.3 & 85.4 & 85.5 & 85.2 & 84.6 & 84.4 & 85.1 & 84.0 & 86.2 & 86.6 & 86.8 & 86.5 & 86.5 & 86.5 & 86.6 & 86.9 & 86.9 \\
\hline 84.0 & 83.6 & 84.2 & 84.5 & 85.3 & 84.2 & 84.1 & 84.9 & 84.6 & 84.2 & 86.8 & 85.9 & 86.4 & 86.2 & 85.7 & 85.8 & 86.0 & 85.7 & 86.2 \\
\hline 91.6 & 86.5 & 87.7 & 87.3 & 87.0 & 86.5 & 85.9 & 85.9 & 85.7 & 85.9 & 86.9 & 87.9 & 87.9 & 87.6 & 88.2 & 87.8 & 87.8 & 88.2 & 87.9 \\
\hline 91.7 & 85.9 & 87.4 & 86.1 & 86.2 & 85.6 & 85.0 & 85.5 & 85.4 & 85.6 & 86.3 & 87.6 & 88.4 & 88.1 & 88.4 & 87.9 & 87.9 & 88.4 & 87.9 \\
\hline 92.1 & 86.9 & 88.2 & 86.6 & 88.0 & 87.0 & 85.6 & 85.7 & 85.2 & 86.2 & 86.6 & 88.6 & 89.7 & 89.7 & 90.5 & 89.3 & 89.0 & 89.1 & 89.0 \\
\hline 91.6 & 87.2 & 88.9 & 87.0 & 88.4 & 87.3 & 86.2 & 86.6 & 86.1 & 87.1 & 86.7 & 89.0 & 89.8 & 89.8 & 90.6 & 89.7 & 89.3 & 89.3 & 89.1 \\
\hline- & 86.4 & 88.1 & 87.6 & 87.9 & 87.0 & 85.7 & 86.8 & 86.5 & 86.1 & 87.2 & 87.9 & 88.8 & 88.8 & 88.0 & 87.7 & 87.9 & 87.2 & 86.8 \\
\hline 15.0 & - & 90.7 & 89.2 & 87.9 & 88.4 & 86.7 & 87.5 & 86.8 & 87.8 & 86.8 & 87.5 & 86.3 & 86.0 & 87.3 & 86.9 & 87.3 & 87.3 & 86.3 \\
\hline 13.0 & 10.0 & - & 90.2 & 92.4 & 90.3 & 89.4 & 89.1 & 89.0 & 89.3 & 89.4 & 89.7 & 89.1 & 89.1 & 89.1 & 89.7 & 89.5 & 89.5 & 89.0 \\
\hline 13.6 & 11.6 & 10.5 & - & 90.1 & 89.5 & 89.6 & 87.8 & 87.3 & 87.3 & 87.6 & 89.5 & 88.2 & 88.0 & 88.3 & 88.6 & 88.8 & 89.2 & 88.8 \\
\hline 13.2 & 13.2 & 8.0 & 10.6 & - & 91.1 & 92.2 & 89.4 & 89.8 & 88.8 & 88.8 & 89.5 & 88.7 & 88.6 & 88.9 & 89.4 & 89.2 & 89.0 & 89.2 \\
\hline 14.3 & 12.6 & 10.4 & 11.3 & 9.5 & - & 91.6 & 87.8 & 88.2 & 88.1 & 86.2 & 88.4 & 87.9 & 87.8 & 88.3 & 88.2 & 88.3 & 88.2 & 88.3 \\
\hline 15.8 & 14.7 & 11.5 & 11.2 & 8.2 & 8.9 & - & 89.8 & 89.2 & 87.3 & 85.3 & 89.1 & 87.2 & 87.1 & 87.8 & 87.9 & 88.1 & 88.0 & 88.3 \\
\hline 14.5 & 13.7 & 11.7 & 13.3 & 11.4 & 13.3 & 10.9 & $\infty$ & 97.4 & 93.7 & 88.7 & 89.6 & 88.8 & 88.6 & 88.4 & 88.7 & 88.5 & 88.9 & 88.7 \\
\hline 14.9 & 14.6 & 11.8 & 13.9 & 10.9 & 12.8 & 11.6 & 2.7 & - & 93.2 & 88.2 & 89.6 & 88.8 & 88.6 & 88.0 & 88.9 & 88.7 & 89.2 & 89.1 \\
\hline 15.4 & 13.3 & 11.5 & 13.9 & 12.1 & 12.9 & 13.9 & 6.6 & 7.1 & - & 88.6 & 88.6 & 87.8 & 87.7 & 87.9 & 88.2 & 88.0 & 88.0 & 87.4 \\
\hline 14.0 & 14.5 & 11.4 & 13.6 & 12.2 & 15.2 & 16.3 & 12.2 & 12.9 & 12.4 & - & 90.2 & 89.7 & 89.4 & 90.0 & 90.0 & 90.2 & 90.0 & 89.7 \\
\hline 13.2 & 13.6 & 11.0 & 11.4 & 11.3 & 12.6 & 11.7 & 11.2 & 11.2 & 12.4 & 10.5 & - & 93.9 & 94.2 & 94.5 & 95.3 & 95.4 & 95.1 & 95.1 \\
\hline 12.1 & 15.1 & 11.8 & 12.8 & 12.3 & 13.2 & 14.0 & 12.1 & 12.2 & 13.3 & 11.1 & 6.3 & - & 99.6 & 96.4 & 96.0 & 95.9 & 95.9 & 96.4 \\
\hline 12.2 & 15.5 & 11.8 & 13.1 & 12.4 & 13.4 & 14.2 & 12.3 & 12.4 & 13.5 & 11.4 & 6.1 & 0.4 & - & 96.3 & 95.7 & 95.9 & 95.7 & 96.2 \\
\hline 13.1 & 14.0 & 11.7 & 12.7 & 12.0 & 12.7 & 13.3 & 12.6 & 13.1 & 13.2 & 10.7 & 5.8 & 3.7 & 3.8 & - & 97.1 & 97.3 & 97.2 & 96.7 \\
\hline 13.4 & 14.4 & 11.1 & 12.3 & 11.4 & 12.9 & 13.2 & 12.2 & 12.0 & 12.9 & 10.7 & 4.8 & 4.1 & 4.4 & 3.0 & - & 98.5 & 97.7 & 97.1 \\
\hline 13.2 & 14.0 & 11.3 & 12.1 & 11.7 & 12.7 & 13.0 & 12.5 & 12.3 & 13.1 & 10.5 & 4.8 & 4.2 & 4.2 & 2.8 & 1.5 & - & 98.4 & 97.7 \\
\hline 14.0 & 14.0 & 11.3 & 11.7 & 11.9 & 12.8 & 13.1 & 12.0 & 11.7 & 13.1 & 10.7 & 5.1 & 4.2 & 4.4 & 2.9 & 2.3 & 1.7 & - & 98.4 \\
\hline 14.5 & 15.1 & 11.9 & 12.2 & 11.7 & 12.7 & 12.7 & 12.3 & 11.8 & 13.7 & 11.0 & 5.1 & 3.7 & 3.9 & 3.4 & 3.0 & 2.4 & 1.7 & - \\
\hline
\end{tabular}

drate profiles of all of the strains studied are shown in Table 8 .

\section{DISCUSSION}

In an attempt to identify a large number of veterinary isolates, numerical comparisons of the whole-cell protein and fatty acid contents were used as a first step in the identification process. A total of 21 gram-negative avian isolates had strikingly similar profiles (Fig. 1 and Table 2) which were clearly different from the profiles of all other organisms present in our data bases. Such very high levels of similarity in protein and fatty acid contents for the most part reflect very close genotypic relatedness as well $(38,50-52$, $55)$. DNA binding studies performed with a representative sample of these 21 isolates confirmed that all of the strains belong to a single genospecies (DNA binding values were greater than 93\% [Table 3]). In order to establish the phylogenetic affiliation of this taxon, we performed DNArRNA hybridization experiments with four selected strains and reference strains belonging to the six rRNA superfamilies sensu De Ley (49). We also determined the nearly complete 16S rRNA sequence and compared it with about 450 sequences representing the various evolutionary lineages within the Bacteria (56).

An extensive DNA-rRNA hybridization analysis revealed the position of this taxon on a separate phylogenetic branch within rRNA superfamily V (Fig. 2). Among other taxa, the genera Flavobacterium, Cytophaga, Capnocytophaga, and Riemerella are present in the same taxonomic neighborhood (Fig. 2) (45). However, the nearest neighbors of the new taxon are situated at a difference in $T_{m(e)}$ of about $13^{\circ} \mathrm{C}$ (Fig. $2)$. Usually, the $T_{m(e)}$ range within a genus is about $5^{\circ} \mathrm{C}(11)$. This clearly indicates that the 21 strains belong to a very distinct, new genus. The difference in $T_{m(e)}$ of about $13^{\circ} \mathrm{C}$ corresponds to the genomic range found within several well-characterized bacterial families (49). At present, proposing a name for this family seems premature as it is generally accepted that the taxonomy of related genera, such as Flavobacterium and Cytophaga, has to be revised thoroughly. A comparison of the 16S rRNA sequence of strain LMG $9086^{\mathrm{T}}$ with other bacterial $16 \mathrm{~S}$ rRNA sequences in our data base confirmed the placement of this organism in the Flavobacterium-Cytophaga rRNA cluster. It is well-known that rRNA sequencing is more powerful than DNA-rRNA hybridization for establishing relationships at deep phylogenetic levels (i.e., between families or classes) (57). A detailed scheme of the relationships between the new organism and its closest allies is shown in Fig. 3. Obviously, the new taxon is most closely related to species in the "flavobacter" subgroup of the "flavobacter-bacteroides" phylum as described by Gherna and Woese (20). It falls in the "flavobacter" subgroup and is about equally related to the two clusters of Flavobacterium species. Flavobacterium meningosepticum and Flavobacterium breve are its nearest neighbors and are related at a similarity level of $89.9 \%$. This low 


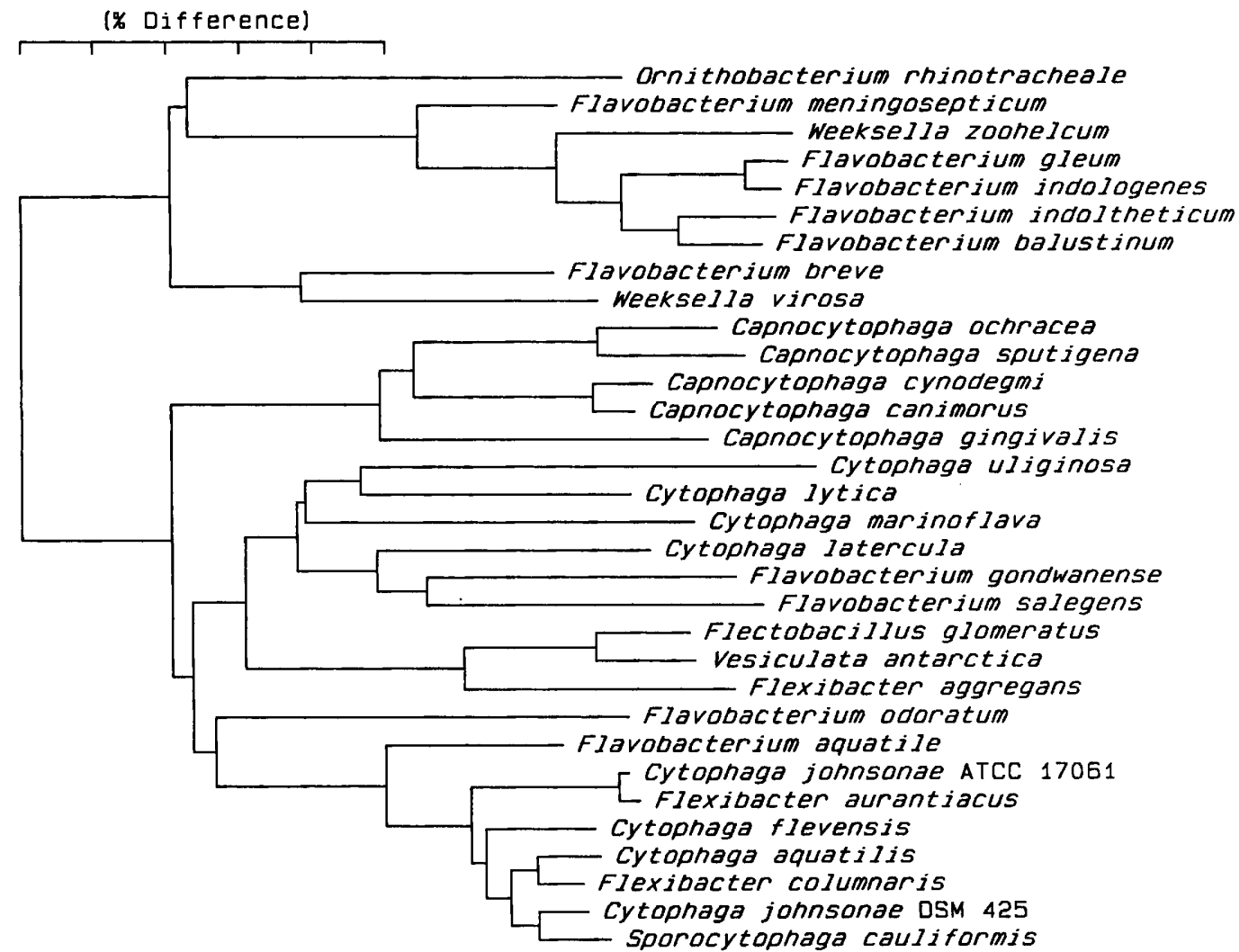

FIG. 3. Phylogenetic tree for $O$. rhinotracheale and 31 reference species based on $16 \mathrm{~S}$ rRNA sequence similarity values. The scale bar represents 0 to $5 \%$ differences in nucleotide sequences as determined by measuring the lengths of the horizontal lines connecting any two species.

similarity level again indicates that there is a large genetic distance between the new taxon and its closest relatives. Also from the viewpoint of direct sequencing, this genetic distance corresponds to the genomic range within several bacterial families (e.g., the family Cardiobacteriaceae, whose members cluster at a similarity level of more than 93\% [15]). We therefore propose a new genus, Ornithobacterium, and a new species, $O$. rhinotracheale, to accommodate this taxon.

Identification of $O$. rhinotracheale strains. Typical members of the Flavobacterium-Cytophaga rRNA cluster are readily identified on the basis of their flexirubin type pigments. However, strains that produce only weak or no colonial pigments on common isolation media must be recognized in other ways. It has been emphasized previously that chemotaxonomic markers such as respiratory quinones, cellular fatty acids, and cellular carbohydrates are valuable parameters for the identification of these organisms $(2,5,6,8,9$, $22,35,39,43,47,48$ ). From the viewpoint of veterinary microbiology, it is important to differentiate $O$. rhinotracheale from $R$. anatipestifer as these two taxa share the same ecological niche and have several features in common. In fact, several $O$. rhinotracheale strains were initially identified as $R$. anatipestifer or as $R$. anatipestifer-like (59). Another member of the same rRNA cluster, the genus Capnocytophaga, has a similar type of capnophilic metabolism and shares a number of phenotypic features with $O$. rhinotracheale and $R$. anatipestifer (see below). We therefore included a reference strain of each of the five Capnocytophaga species and five representative $R$. anatipestifer strains in several phenotypic analyses in order to evaluate the differentiation of the three genera.

All $O$. rhinotracheale and $R$. anatipestifer strains have very similar protein contents $(r>89 \%)$ (Fig. 1). More variability was observed in the five Capnocytophaga strains. This variability was expected as each strain represents a different species (Table 1 and Fig. 1). In general, a comparison of the protein profiles results in clear-cut differentiation among $O$. rhinotracheale, $R$. anatipestifer, and Capnocytophaga species; each of these taxa constitutes a distinct electrophoretic cluster (Fig. 1).

All three taxa are characterized by very high percentages of branched-chain fatty acids $(>87 \%)$. Similar data for $R$. anatipestifer and Capnocytophaga species have been reported previously $(2,9,22,39,43,45,47,48)$. For each taxon, 15:0 iso accounts for more than one-half of the total fatty acid content (Table 2). The relative amounts of 13:0 iso, 15:0 anteiso, 15:0 iso $3 \mathrm{OH}, 17: 0$ iso $3 \mathrm{OH}$, and an unidentified fatty acid with an equivalent chain length of 13.566 can easily be used as differential features (see above). As reported previously (47), strains of different Capnocytophaga species have very similar fatty acid compositions (Table 2).

As is common in other members of the FlavobacteriumCytophaga rRNA cluster, menaquinones were the only respiratory quinones detected $(5,8,18,47)$. $O$. rhinotracheale LMG 11553 and LMG 11556 reportedly contain menaquinone 7 as their only respiratory quinones, which is similar to the quinone composition of $R$. anatipestifer (18). Capnocytophaga species contain menaquinone 6 and trace amounts of menaquinone $5(6,47)$. 


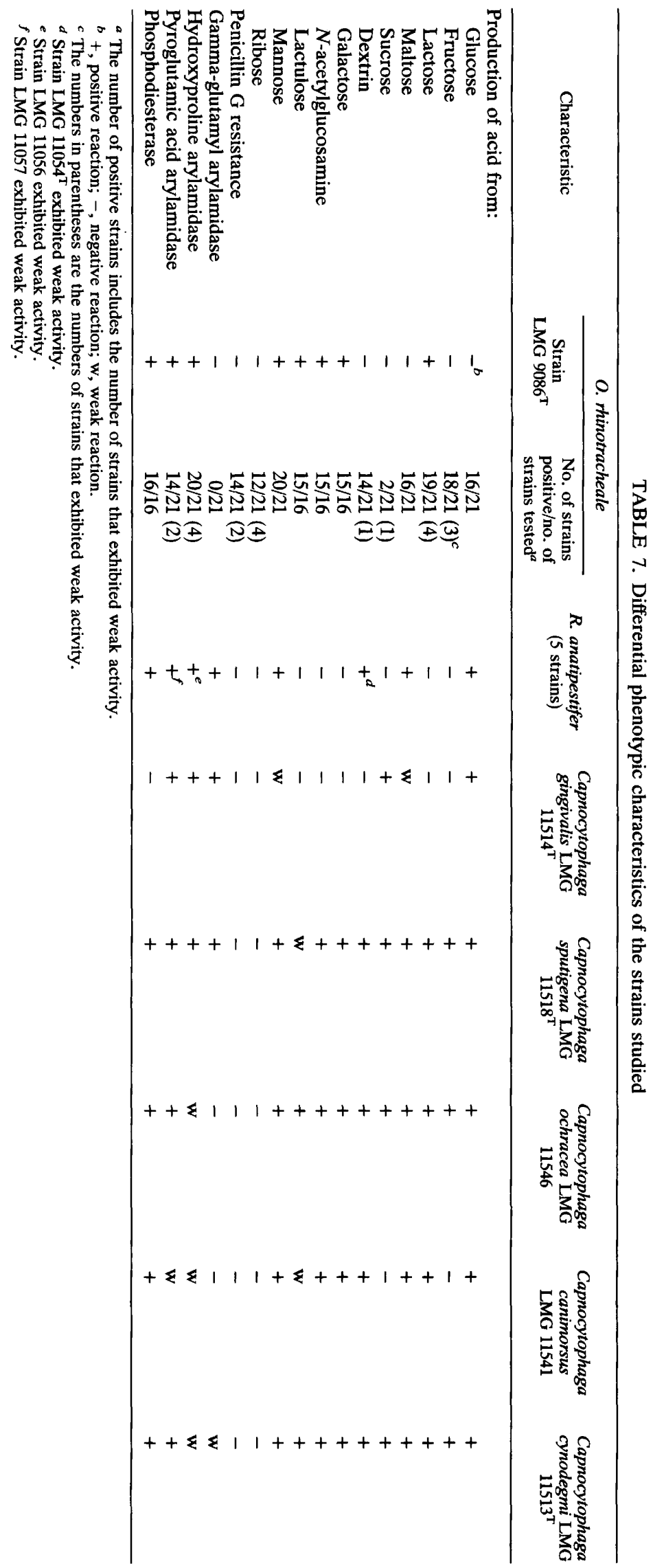


TABLE 8. Carbohydrate profiles of $19 O$. rhinotracheale strains

\begin{tabular}{|c|c|c|c|c|c|c|c|c|c|c|c|c|c|c|c|c|c|c|c|c|}
\hline \multirow{2}{*}{$\begin{array}{l}\text { Retention } \\
\text { time } \\
\text { (min) }\end{array}$} & \multirow{2}{*}{ Carbohydrate ${ }^{a}$} & \multicolumn{19}{|c|}{ Peak areas ${ }^{b}$} \\
\hline & & $\begin{array}{l}\text { LMG } \\
9085\end{array}$ & $9086^{T}$ & 9087 & $\begin{array}{c}\text { LMG } \\
9088\end{array}$ & $\begin{array}{l}\text { LMG } \\
10960\end{array}$ & 10961 & 10967 & 710968 & 10969 & 11342 & $\begin{array}{l}\text { LMG } \\
211343\end{array}$ & $\begin{array}{l}\text { LMG } \\
11553^{c}\end{array}$ & $\begin{array}{l}\text { LMG } \\
11554^{c}\end{array}$ & $\begin{array}{l}\text { LMG } \\
11555\end{array}$ & $\begin{array}{l}\text { LMG } \\
11556^{c}\end{array}$ & $\begin{aligned} & \text { LMG } \\
& 12589\end{aligned}$ & 12591 & 112599 & $\begin{array}{l}\text { LMG } \\
12600\end{array}$ \\
\hline 10.99 & Erythritol & (3) & - & - & - & - & - & - & - & - & - & - & - & - & - & - & - & - & 1 & - \\
\hline 11.12 & Fucosylamine (A) (?) & - & - & - & - & - & (4) & - & - & - & 3 & - & - & - & 3 & - & - & - & 1 & (2) \\
\hline 11.44 & $\mathrm{C}_{5}$ & (3) & - & 3 & - & - & - & (3) & - & - & - & - & 4 & 5 & 3 & 4 & 3 & 3 & 3 & 3 \\
\hline 11.67 & $\mathrm{C}_{5}-\mathrm{CH}_{3}(?)$ & - & - & - & - & - & - & - & - & - & - & - & 一 & - & - & - & 一 & - & 3 & 2 \\
\hline 11.98 & $\mathrm{C}_{5}$ & - & - & - & - & - & - & - & - & - & - & - & 3 & 4 & (3) & 3 & 3 & 2 & 3 & 3 \\
\hline 12.09 & Ribose (A) & 5 & - & 6 & - & 6 & - & 5 & 4 & 4 & 6 & 6 & 6 & 7 & 4 & 4 & (3) & 3 & - & (2) \\
\hline 12.18 & Fucose (A) & 4 & - & 3 & - & - & 4 & - & 5 & 4 & 一 & - & - & - & 8 & - & (2) & - & 6 & (2) \\
\hline 12.23 & $\mathrm{C}_{5}$ & - & - & - & - & - & - & - & - & - & (3) & - & - & - & - & - & - & - & - & - \\
\hline 12.80 & $\mathrm{C}_{6}$ & - & - & - & - & - & - & - & - & - & - & - & - & - & - & - & 2 & - & 1 & - \\
\hline 13.29 & Lyxose (A) & 3 & - & - & 4 & 4 & - & 5 & 4 & 4 & 4 & 5 & 4 & 4 & 6 & 4 & 5 & 4 & 5 & 5 \\
\hline 13.34 & Rhamnose (A & - & - & - & - & - & 2 & - & 5 & - & - & - & - & - & - & - & - & - & - & - \\
\hline 13.50 & Threose (?) & - & - & - & - & - & - & - & - & 2 & $\ldots$ & - & - & - & - & - & - & - & (1) & - \\
\hline 13.56 & Lyxos & 5 & 3 & - & 6 & 6 & 4 & 7 & 6 & 6 & 6 & 6 & 6 & 7 & 7 & 6 & (7) & 6 & 7 & (8) \\
\hline 13.63 & Rhamnose (C & 3 & - & - & - & - & 4 & - & 7 & 3 & 3 & - & 4 & - & - & - & - & 1 & - & - \\
\hline 13.68 & Fucose & - & - & - & - & - & - & - & - & 4 & 3 & - & - & - & - & - & (3) & - & - & 2 \\
\hline 13.69 & Arabinose (A & - & - & - & - & - & - & - & - & 4 & - & - & - & - & - & - & (2) & (3) & 2 & - \\
\hline 13.75 & (O) (?) & (3) & (4) & (3) & - & - & - & (3) & - & - & (3) & - & - & - & - & - & - & - & - & (2) \\
\hline 13.91 & Arabinose $(\mathrm{O})$ & - & - & - & - & - & - & - & - & - & - & - & - & - & - & - & 1 & 2 & 1 & 1 \\
\hline 14.51 & $\mathrm{C}_{5}$-ol (?) & 一 & - & - & - & (1) & - & - & - & - & - & - & - & - & - & - & 1 & - & 1 & - \\
\hline 15.28 & $\mathrm{C}_{6}$-ol & 4 & - & 5 & - & 4 & - & - & - & (3) & 2 & - & 4 & 3 & - & 4 & 3 & 3 & 3 & 3 \\
\hline 15.32 & $\mathrm{C}_{6}(?)$ & - & - & - & - & (1) & (2) & - & - & (4) & - & - & - & - & - & - & (3) & 2 & 2 & - \\
\hline 15.41 & Mannose (A) & 5 & 5 & 5 & 5 & 4 & 3 & 4 & 4 & 4 & 4 & 3 & 4 & 3 & 5 & 3 & 3 & 4 & 5 & 5 \\
\hline 15.47 & & - & - & - & (3) & - & - & - & - & - & - & - & - & - & - & - & (2) & 2 & 1 & 2 \\
\hline 15.54 & Gluce & 3 & 4 & 4 & 5 & 5 & 5 & - & 4 & 4 & 4 & 4 & 4 & - & 5 & 3 & 3 & 4 & 4 & 4 \\
\hline 15.78 & $\mathrm{C}_{6}-\mathrm{a}$ & - & - & - & - & - & - & - & - & - & - & - & 2 & - & - & - & - & - & - & - \\
\hline 15.83 & Galac & 5 & 7 & 5 & 5 & 6 & 4 & 5 & 5 & 4 & 5 & 4 & 4 & 4 & 5 & 2 & 4 & 4 & 6 & 3 \\
\hline 16.32 & Galact & 4 & 4 & 5 & 3 & 4 & 6 & 5 & 4 & 5 & 6 & 3 & 3 & - & 3 & - & 5 & 4 & 4 & 3 \\
\hline 16.42 & Mannose (O) & 3 & 3 & - & 3 & 3 & 3 & 4 & (3) & 4 & 4 & - & 2 & - & 2 & 3 & 3 & 3 & 3 & 3 \\
\hline 16.60 & Allo & - & 4 & (3) & - & - & 3 & (3) & 3 & 2 & 3 & - & 2 & - & 3 & - & - & 3 & 2 & (3) \\
\hline 16.70 & Mann & 5 & 6 & 6 & 5 & 6 & 5 & 5 & (5) & 6 & 6 & 5 & 4 & 3 & 3 & 5 & (5) & 5 & 5 & 4 \\
\hline 16.75 & Glucose (O) & 3 & 4 & 4 & 5 & 4 & 5 & 4 & 5 & 4 & 6 & 5 & 4 & - & 4 & 3 & 3 & 4 & 4 & 5 \\
\hline 16.85 & Galact & 5 & 6 & 6 & 5 & 5 & 7 & 5 & 6 & 7 & 7 & 5 & 5 & 3 & 4 & 3 & 6 & 6 & 6 & 4 \\
\hline 17.01 & Sorbo & - & - & - & - & - & - & - & - & - & 一 & - & - & - & - & - & 1 & - & - & - \\
\hline 17.14 & Gluc & - & - & - & - & - & - & (6) & - & - & - & - & - & - & - & - & 5 & 3 & $(2)$ & 3 \\
\hline 17.23 & Inositol & - & - & - & - & - & - & (3) & - & - & - & - & - & - & - & - & (2) & - & 5 & - \\
\hline 17.76 & $\mathrm{C}_{5}$-phenyl & - & - & - & - & (3) & - & - & - & - & - & - & - & - & (3) & - & (3) & 3 & 3 & 4 \\
\hline 18.11 & Galac & 一 & - & - & - & - & - & - & - & - & - & - & - & 一 & - & - & 4 & 4 & 4 & 3 \\
\hline 18.46 & Gala & - & - & - & - & - & - & (4) & - & - & - & - & - & - & - & - & 3 & 2 & (3) & (2) \\
\hline 18.54 & Gluc & - & - & - & - & - & - & - & - & (3) & - & - & - & - & - & - & (5) & - & (5) & (3) \\
\hline 18.59 & Mannosamine & - & - & - & - & - & - & (7) & - & - & - & - & - & - & - & - & (5) & 4 & (5) & 3 \\
\hline 18.75 & Galactosamine (?) & (3) & (3) & (3) & - & 4 & - & - & - & 3 & 3 & - & - & - & - & 4 & 4 & 5 & 4 & (4) \\
\hline
\end{tabular}

${ }^{a}$ Abbreviations for reaction types: A, peracetylated aldononitrile; $\mathrm{O}$, peracetylated O-methyloxime; $\mathrm{C}_{5}$ and $\mathrm{C}_{6}$, unknown carbohydrates with five and six carbon atoms, respectively; -ol, sugar alcohol; phenyl, phenylated carbohydrate; $\mathrm{CH}_{3}$, methylated carbohydrate. When no reaction type is specified, only acetylation was observed (with sugar alcohols, amino sugars, and similar compounds). ?, identity of carbohydrate was uncertain.

$b 1,0.1$ to $0.5 \% ; 2,0.5$ to $1.0 \% ; 3,1.1$ to $3.0 \% ; 4,3.1$ to $6.0 \% ; 5,6.1$ to $10.0 \% ; 6,10.1$ to $20.0 \% ; 7,20.1$ to $30.0 \% ; 8$, more than $30.0 \%$; - , not detected. Values in parentheses indicate that the reactions were variable (carbohydrate was not detected in all samples); at least five samples were examined for each carbohydrate.

${ }^{c}$ Preliminary data have been reported previously (36).

$O$. rhinotracheale can be further differentiated from $R$. anatipestifer by the absence of catalase activity and by the presence of $\beta$-glucosaminidase activity and $\alpha$ - and $\beta$-galactosidase activity $(R$. anatipestifer strains have the opposite reactions for these tests [42]). Additional characteristics were determined by using experimental API galleries (Table 7). $O$. rhinotracheale strains do not exhibit gamma-glutamyl arylamidase activity, and most strains produce acid from fructose (18 of 21 strains), lactose (19 of 21 strains), galactose (15 of 16 strains), and $N$-acetyl-glucosamine (15 of 16 strains), whereas the five reference strains of $R$. anatipestifer have the opposite reactions. The absence of catalase activity and the presence of oxidase activity should allow workers to differentiate $O$. rhinotracheale from Capnocytophaga species; Capnocytophaga sputigena, Capnocytophaga gingivalis, and Capnocytophaga ochracea do not ex- hibit catalase or oxidase activity, while Capnocytophaga canimorsus and Capnocytophaga cynodegmi produce both catalase and oxidase (4). Additional characteristics are shown in Table 7.

A relatively new approach in bacterial taxonomy is the determination of cellular carbohydrate contents $(3,37)$. The presence of an unidentified $\mathrm{C}_{5}$ compound with retention times of 11.44 and $11.98 \mathrm{~min}$, the presence of $\mathrm{a}_{6}$ compound with a retention time of $15.28 \mathrm{~min}$, the presence of ribose, the presence of large amounts of lyxose, mannose, glucose, and galactose, and the lack of arabinose (except in strains LMG 10969, LMG 12589, LMG 12591, and LMG 12599), sorbose, and heptoses are general properties of organisms belonging to rRNA superfamily $\mathrm{V}$, whereas this general carbohydrate pattern has not been observed in members of the other rRNA superfamilies investigated so far (21). 
3-Deoxy-D-mannooctulosonic acid was not observed. This could have been because of the derivatization technique used, which was not optimal for this compound, or because there was a proportionally low level of 3-deoxy-D-mannooctulosonic acid present. The differences determined for the hexosamines glucosamine, galactosamine, and mannosamine are of minor taxonomic importance.

Description of Ornithobacterium gen. nov. Ornithobacterium (Or.ni.tho.bac.te'ri.um. Gr. n. ornis, bird; Gr. neut. n. bakterion, rod; N. L. neut. n. Ornithobacterium, bird bacterium, because the organism was first isolated from birds). Ornithobacterium cells are gram-negative, nonmotile, nonsporulating, short, plump rods with chemoorganotrophic, mesophilic metabolism. Ornithobacterium strains grow under various atmospheric conditions at temperatures between 30 and $42^{\circ} \mathrm{C}$. Colonies are not pigmented on common growth media. Menaquinone 7 is the sole respiratory quinone. The branched fatty acids $15: 0$ iso, $15: 0$ iso $3 \mathrm{OH}$, and 17:0 iso $3 \mathrm{OH}$ are the major fatty acid components. The DNA base composition ranges from 37 to $39 \mathrm{~mol} \% \mathrm{G}+\mathrm{C}$. The type species is $O$. rhinotracheale sp. nov.

Description of Ornithobacterium rhinotracheale sp. nov. Ornithobacterium rhinotracheale (rhi.no.tra.che.a'le. Gr. n. ris nose, nostril; medical term trachea, windpipe; L. neut. adj. suff. -ale, pertaining to; N. L. neut. adj. rhinotracheale, relating to nostrils and windpipes, because the organism was first isolated from specimens obtained from windpipes and nostrils). $O$. rhinotracheale cells are 0.2 to $0.9 \mu \mathrm{m}$ wide and 1 to $3 \mu \mathrm{m}$ long. Most strains grow aerobically, microaerobically, anaerobically, and in a $\mathrm{CO}_{2}$-enriched atmosphere. Growth occurs at 30,35 , and $42^{\circ} \mathrm{C}$. Weak or no growth occurs at $24^{\circ} \mathrm{C}$. After storage for 6 weeks at 6 to $8^{\circ} \mathrm{C}$, blood agar cultures can be subcultured on blood agar. Colonial adherence, spreading, and corrosion do not occur. No hemolysis occurs on horse blood agar. Smooth, nonpigmented colonies develop after 2 days of incubation on rich peptone, peptone-blood, or chocolate agar at $36^{\circ} \mathrm{C}$. Oxidase activity is present in most strains; catalase activity is absent. No growth occurs on MacConkey agar, Endo agar, Drigalski agar, or Simmons citrate medium. No growth factors are required. Alkaline phosphatase and $\beta$-galactosidase $(o$-nitrophenyl- $\beta$-D-galactopyranoside test) are present. Nitrates are not reduced; some strains reduce nitrites, but no denitrification occurs. Arginine dihydrolase is present in most strains if the strains are grown in Möller medium (Difco) after 3 days of incubation at $36^{\circ} \mathrm{C}$. Lysine and ornithine decarboxylase, phenylalanine deaminase, lecithinase, DNase, and gelatinase activities are absent. Urease activity as determined by Lautrop's nonproliferative test (30) is present. Indole is not produced. Hydrogen sulfide is not detected in Kligler's agar, triple sugar iron agar, or SIM agar. Esculin is not hydrolyzed. Acetylmethylcarbinol is produced in the VogesProskauer test. Methyl red test negative. Hyaluronidase and chondroitin sulfatase activities are present. Ethanol is not oxidized. D-Glucose in oxidation-fermentation medium is weakly and slowly oxidized or not detected. Wheat starch is acidified by most strains. Most strains use D-galactose, D-glucose, D-mannose, lactose, and sucrose as carbon sources. D-Xylose, D-mannitol, D-sorbitol, and malonate are not used by most strains as carbon sources. In general, carbohydrates are catabolized better in media supplemented with $2 \%$ chicken serum. Wheat starch is acidified by most strains within 1 to 5 days if cultures are incubated at $36^{\circ} \mathrm{C}$.

The following enzyme activities are always present: alkaline and acid phosphatase, ester lipase $\mathrm{C} 8$, leucine arylamidase, phosphoamidase, $\alpha$-glucosidase, $\beta$-glucosaminidase, phosphodiesterase, alanine arylamidase, glycine arylamidase, lysine arylamidase, proline arylamidase, $\alpha$-glutamyl- $\alpha$ glutamic acid arylamidase, glycyl-phenylalanine arylamidase, phenylalanyl-arginine arylamidase, prolyl-arginine arylamidase, seryl-methionine arylamidase, 2-glycyl-glycylarginine arylamidase, and alanyl-phenylalanyl-prolyl-alanine arylamidase. All strains exhibit strong or weak $\alpha$ - and $\beta$-galactosidase, esterase $\mathrm{C} 4$, valine and cysteine arylamidase, and trypsin activities. The following enzyme activities are always absent: $\beta$-glucuronidase, $\beta$-glucosidase, $\alpha$-mannosidase, $\alpha$-fucosidase, lipase $\mathrm{C} 14$, phenylalanine deaminase, hippurate hydrolysis, gamma-glutamyl arylamidase, and phospholipase. No acid is produced from D-glucosaminic acid, D-saccharic acid, L-fucose, D-mannitol, D-sorbitol, trehalose, and D-xylose.

The additional fatty acids present in small quantities in all strains include two unidentified fatty acids with equivalent chain lengths of 13.566 and 16.580, 16:0, 17:0 iso, and 16:0 $3 \mathrm{OH}$.

Lyxose, ribose, glucose, galactose, and mannose are the principal carbohydrate components, while altrose, sorbose, and heptose do not occur.

Strains have been isolated from respiratory tracts of turkeys, chickens, rooks, and a partridge, and most strains have been associated with infections such as tracheitis, pericarditis, sinusitis, airsacculitis, and pneumonia. At present, our knowledge with regard to pathogenicity in birds is incomplete. Our clinical observations and the results of diagnostic work (unpublished data) indicate with a high level of probability that $O$. rhinotracheale is able to produce a contagious disease. However, it is not yet clear whether cofactors are involved in pathogenesis.

The DNA base composition ranges from 37 to $39 \mathrm{~mol} \%$ $\mathrm{G}+\mathrm{C}$. The type strain is LMG 9086 (= MCCM $01774=$ CCUG 23171), which was isolated from a turkey in the United Kingdom. Its $\mathrm{G}+\mathrm{C}$ content is $38 \mathrm{~mol} \%$.

All $O$. rhinotracheale strains have been deposited in the Culture Collection of the Laboratorium voor Microbiologie and the Culture Collection of the University of Göteborg Department of Clinical Bacteriology.

\section{ACKNOWLEDGMENTS}

We thank Urbain Torck and Dirk Dewettinck for excellent technical assistance. We are especially grateful to T. O. MacAdoo, Department of Foreign Languages, Virginia Polytechnic Institute and State University, Blacksburg, for his expert advice in naming Ornithobacterium rhinotracheale.

We thank all depositors of strains listed in Table 1. P.V. is indebted to the National Fund for Scientific Research (Belgium) for a position as a postdoctoral research fellow. K.K. is indebted to the Fund for Medical Scientific Research, Belgium, for research and personnel grants. Part of this research was performed within the framework of CEC BRIDGE project BIOT-CT91-0294.

\section{REFERENCES}

1. Aiba, H., S. Adhya, and B. de Crombrugghe. 1981. Evidence for two functional gal promoters in intact Escherichia coli cells. J. Biol. Chem. 256:11905-11910.

2. Bangun, A., and D. N. Tripathy. 1986. Taxonomy of Pasteurella anatipestifer. II. Cellular fatty-acid profile by gas chromatography. Avian Dis. 31:46-51.

3. Böhning, A., K. Steinbach, and R. Mutters. 1989. Rapid identification of Haemophilus influenzae serovar b by gas-liquid chromatography using carbohydrate fingerprints. Zentralbl. Bakteriol. Hyg. A 272:19-29.

4. Brenner, D. J., D. G. Hollis, G. R. Fanning, and R. E. Weaver. 1989. Capnocytophaga canimorsus sp. nov. (formerly CDC 
group DF-2), a cause of septicemia following dog bite, and $C$. cynodegmi sp. nov., a cause of localized wound infection following dog bite. J. Clin. Microbiol. 27:231-235.

5. Callies, E., and W. Mannheim. 1978. Classification of the Flavobacterium-Cytophaga complex on the basis of respiratory quinones and fumarate respiration. Int. J. Syst. Bacteriol. 28:14-19.

6. Collins, M. D., H. N. Shah, A. S. McKee, and R. M. Kroppenstedt. 1982. Chemotaxonomy of the genus Capnocytophaga. J. Appl. Bacteriol. 52:409-415.

7. Cowan, S. T. 1974. Cowan and Steel's manual for the identification of medical bacteria, 2nd ed., p. 166-180. Cambridge University Press, London.

8. Dees, S. B., G. M. Carlone, D. Hollis, and C. W. Moss. 1985. Chemical and phenotypic characteristics of Flavobacterium thalpophilum compared with those of other Flavobacterium and Sphingobacterium species. Int. J. Syst. Bacteriol. 35:16-22.

9. Dees, S. B., D. E. Karr, D. Hollis, and C. W. Moss. 1982. Cellular fatty acids of Capnocytophaga species. J. Clin. Microbiol. 16:779-783.

10. De Ley, J. 1970. Reexamination of the association between melting point, buoyant density, and chemical base composition of deoxyribonucleic acid. J. Bacteriol. 101:738-754.

11. De Ley, J. 1991. The Proteobacteria: ribosomal RNA cistron similarities and bacterial taxonomy, p. 2111-2140. In A. Balows, H. G. Trüper, M. Dworkin, W. Harder, and K.-H. Schleifer (ed.), The prokaryotes, 2nd ed., vol. 2. SpringerVerlag, Berlin.

12. De Ley, J., H. Cattoir, and A. Reynaerts. 1970. The quantitative measurement of DNA hybridization from renaturation rates. Eur. J. Biochem. 12:133-142.

13. De Ley, J., and J. De Smedt. 1975. Improvements on the membrane filter method for DNA:rRNA hybridization. Antonie van Leeuwenhoek J. Microbiol. Serol. 41:287-307.

14. De Vos, P., K. Kersters, E. Falsen, B. Pot, M. Gillis, P. Segers, and J. De Ley. 1985. Comamonas Davis and Park 1962 gen. nov., nom. rev. emend., and Comamonas terrigena Hugh 1962 sp. nov., nom. rev. Int. J. Syst. Bacteriol. 35:443-453.

15. Dewhirst, F. E., B. J. Paster, S. La Fontaine, and J. I. Rood. 1990. Transfer of Kingella indologenes (Snell and Lapage 1976) to the genus Suttonella gen. nov. as Suttonella indologenes comb. nov.; transfer of Bacteroides nodosus (Beveridge 1941) to the genus Dichelobacter gen. nov. as Dichelobacter nodosus comb. nov.; and assignment of the genera Cardiobacterium, Dichelobacter, and Suttonella to Cardiobacteriaceae fam. nov. in the gamma division of Proteobacteria on the basis of $16 \mathrm{~S}$ rRNA sequence comparisons. Int. J. Syst. Bacteriol. 40:426433.

16. Dobson, S. J., R. R. Colwell, T. A. McMeekin, and P. D. Franzmann. 1993. Direct sequencing of the polymerase chain reaction-amplified 16S rRNA gene of Flavobacterium gondwanense sp. nov. and Flavobacterium salegens sp. nov., two new species from a hypersaline antarctic lake. Int. J. Syst. Bacteriol. 43:77-83.

17. Eaton, K. A., F. E. Dewhirst, M. J. Radin, J. G. Fox, B. J. Paster, S. Krakowka, and D. R. Morgan. 1993. Helicobacter acinonyx sp. nov., isolated from cheetahs with gastritis. Int. J. Syst. Bacteriol. 43:99-106.

18. Engelhard, E. 1992. Unterzuchungen zur Chemotaxonomie der Familie Pasteurellaceae anhand von Kapillargaschromatographie zellulärer Kolenhydrate, Hochdruckflüssigkeitschromatographie und Dünnschichtchromatographie zellulärer Lipoide, verschiedener Hydrolasen und Infrarot-Massenspektroskopie. Ph. D. thesis. Philipps-Universität Marburg, Marburg, Germany.

19. Frazier, W. C. 1926. A method for the detection of changes in gelatin due to bacteria. J. Infect. Dis. 39:302-309.

20. Gherna, R., and C. R. Woese. 1992. A partial phylogenetic analysis of the "flavobacter-bacteroides" phylum: basis for taxonomic restructuring. Syst. Appl. Microbiol. 15:513-521.

21. Grebe, M., et al. Unpublished data.

22. Holt, S. C., G. Forcier, and B. J. Takacs. 1979. Fatty acid composition of gliding bacteria: oral isolates of Capnocytoph- aga compared with Sporocytophaga. Infect. Immun. 26:298304.

23. Ingens, R., I. Suzuki, and J. T. Staley. 1989. Gas vacuolate bacteria obtained from marine waters of Antarctica. Curr. Microbiol. 18:261-265.

24. Jukes, T. H., and C. R. Cantor. 1969. Evolution of protein molecules, p. 21-132. In H. N. Munro (ed.), Mammalian protein metabolism, vol. 3. Academic Press, Inc., New York.

25. Kafika, A. 1957. Erfahrungen mit einfachen Untersuchungsmethoden zum Nachweis von Hyaluronidase, Fibrinolysin und Phosphatase bei Staphylokokken. Zentralbl. Bakteriol. Parasitenkd. Infektionskr. Hyg. Abt. 1 Orig. 178:381-385.

26. Kersters, K., and J. De Ley. 1971. Enzymatic test with resting cells and cell-free extracts. Methods Microbiol. 6A:33-52.

27. Kersters, K., K.-H. Hinz, A. Hertle, P. Segers, A. Lievens, 0. Siegmann, and J. De Ley. 1984. Bordetella avium sp. nov., isolated from the respiratory tracts of turkeys and other birds. Int. J. Syst. Bacteriol. 34:56-70.

28. Kilian, M. 1976. A taxonomic study of the genus Haemophilus. J. Gen. Microbiol. 93:9-62.

29. Lane, D. J., B. Pace, G. J. Olsen, D. A. Stahl, M. L. Sogin, and N. R. Pace. 1985. Rapid determination of 16 S ribosomal RNA sequences for phylogenetic analyses. Proc. Natl. Acad. Sci. USA 82:6955-6959.

30. Lautrop, H. 1960. Laboratory diagnosis of whooping cough or Bordetella infections. Bull. W. H. O. 23:15-31.

31. MacFaddin, J. F. 1980. Biochemical tests for the identification of medical bacteria, 2nd ed. The Williams \& Wilkins Co., Baltimore.

32. Mannheim, W., S. Pohl, and R. Holländer. 1980. Die Systematik von Actinobacillus, Haemophilus und Pasteurella: Basenzusammensetzung der DNS, Atmungschinone und kulturellbiochemische Eigenschaften repräsentativer Sammlungsstämme. Zentralbl. Bakteriol. Parasitenkd. Infektionskr. Hyg. Abt. 1 Orig. Reihe A 246:512-540.

33. Marmur, J., and P. Doty. 1962. Determination of the base composition of deoxyribonucleic acid from its thermal denaturation temperature. J. Mol. Biol. 5:109-118.

34. Möller, V. 1955. Simplified tests for some amino acid decarboxylases and for the arginine dihydrolase system. Acta Pathol. Microbiol. Scand. 36:158-172.

35. Mouahid, M. 1992. Chemotaxonomy of the avian Pasteurellaceae and related organisms with special reference to the characterization of species on the basis of cellular carbohydrate profiles. Ph. D. thesis. Rabat, Morocco.

36. Mouahid, M., E. Engelhard, M. Grebe, R. M. Kroppenstedt, R. Mutters, and W. Mannheim. Characterization of nonpigmented members of the Flavobacterium/Cytophaga complex parasitizing in mammals and birds. In P. J. Jooste (ed.), Proceedings of the 2nd International Symposium on Flavobacterium-Cytophaga and related bacteria, in press.

37. Mutters, R. 1991. Capillary gas chromatography of cellular carbohydrates as a means for the differentiation of fastidious, slow-growing or anaerobic Gram-negative bacteria-a review. Zentralbl. Bakteriol. Hyg. A 275:451-466.

38. Owen, R. J., and P. J. H. Jackman. 1982. The similarities between Pseudomonas paucimobilis and allied bacteria derived from analysis of deoxyribonucleic acids and electrophoretic protein patterns. J. Gen. Microbiol. 128:2945-2954.

39. Oyaizu, H., and K. Komagata. 1981. Chemotaxonomic and phenotypic characterization of the strains of species in the Flavobacterium-Cytophaga complex. J. Gen. Appl. Microbiol. 27:57-107.

40. Pace, B., E. A. Matthews, K. D. Johnson, C. R. Cantor, and N. R. Pace. 1982. Conserved 5S rRNA complement to tRNA is not required for protein synthesis. Proc. Natl. Acad. Sci. USA 79:36-40.

41. Paster, B. J., and F. E. Dewhirst. 1988. Phylogeny of campylobacters, wolinellas, Bacteroides gracilis, and Bacteroides ureolyticus by $16 \mathrm{~S}$ ribosomal ribonucleic acid sequencing. Int. J. Syst. Bacteriol. 38:56-62.

42. Piechulla, K., S. Pohl, and W. Mannheim. 1986. Phenotypic and genetic relationships of so-called Moraxella (Pasteurella) 
anatipestifer to the Flavobacterium/Cytophaga group. Vet. Microbiol. 11:261-270.

43. Poen, E., M. Aufderheide, H. Dickmann, and R. M. Kroppenstedt. 1984. Taxonomical studies on filamentous bacteria from sewage belonging to the Flavobacterium-Cytophaga complex. Arch. Microbiol. 137:295-301.

44. Saitou, N., and M. Nei. 1987. The neighbor-joining method: a new method for reconstructing phylogenetic trees. Mol. Biol. Evol. 4:406-425.

45. Segers, P., W. Mannheim, M. Vancanneyt, K. De Brandt, K.-H. Hinz, K. Kersters, and P. Vandamme. Riemerella anatipestifer gen. nov., comb. nov., the causative agent of septicemia anserum exsudativa and its phylogenetic affiliation within the Flavobacterium-Cytophaga rRNA homology group. Int. J. Syst. Bacteriol., in press.

46. Smith, R. F., and N. P. Willet. 1968. Rapid plate method for screening hyaluronidase and chondroitin sulfatase producing microorganisms. Appl. Microbiol. 16:1434-1436.

47. Speck, H., R. M. Kroppenstedt, and W. Mannheim. 1987. Genomic relationships and species differentiation in the genus Capnocytophaga. Zentralbl. Bakteriol. Parasitenkd. Infektionskr. Hyg. Abt. 1 Orig. Reihe A 266:390-402.

48. Sugimoto, C., E. Miyagawa, M. Nakazawa, K. Mitani, and Y. Isayama. 1983. Cellular fatty acid composition comparisons of Haemophilus equigenitalis and Moraxella species. Int. J. Syst. Bacteriol. 33:181-187.

49. Vandamme, P., and J. De Ley. 1991. Proposal for a new family, Campylobacteraceae. Int. J. Syst. Bacteriol. 41:451-455.

50. Vandamme, P., E. Falsen, B. Pot, B. Hoste, K. Kersters, and J. De Ley. 1989. Identification of EF group 22 campylobacters from gastroenteritis cases as Campylobacter concisus. J. Clin. Microbiol. 27:1775-1781.

51. Vandamme, P., B. Pot, E. Falsen, K. Kersters, and J. De Ley. 1990. Intra- and interspecific relationships of veterinary campylobacters revealed by numerical analysis of electrophoretic protein profiles and DNA:DNA hybridizations. Syst. Appl. Microbiol. 13:295-303.

52. Vandamme, P., M. Vancanneyt, B. Pot, L. Mels, B. Hoste, D. Dewettinck, L. Vlaes, C. Van Den Borre, R. Higgins, J. Hommez, K. Kersters, J.-P. Butzler, and H. Goossens. 1992. Polyphasic taxonomic study of the emended genus Arcobacter with Arcobacter butzleri comb. nov. and Arcobacter skirrowii sp. nov., an aerotolant bacterium isolated from veterinary specimens. Int. J. Syst. Bacteriol. 42:344-356.

53. Van Landschoot, A., and J. De Ley. 1983. Intra- and intergeneric similarities of the rRNA cistrons of Alteromonas, Marinomonas (gen. nov.) and some other Gram-negative bacteria. J. Gen. Microbiol. 129:3057-3074.

54. Vauterin, L., J. Swings, and K. Kersters. 1991. Grouping of Xanthomonas campestris pathovars by SDS-PAGE of proteins. J. Gen. Microbiol. 137:1677-1687.

55. Vauterin, L., P. Yang, B. Hoste, M. Vancanneyt, E. L. Civerolo, J. Swings, and K. Kersters. 1991. Differentiation of Xanthomonas campestris pv. citri strains by sodium dodecyl sulfatepolyacrylamide gel electrophoresis of proteins, fatty acid analysis, and DNA-DNA hybridization. Int. J. Syst. Bacteriol. 41:535-542.

56. Winker, S., and C. R. Woese. 1991. A definition of the domains Archaea, Bacteria and Eucarya in terms of small subunit ribosomal RNA characteristics. Syst. Appl. Microbiol. 14:305310.

57. Woese, C. R. 1987. Bacterial evolution. Microbiol. Rev. 51:221271.

58. Woese, C. R., D. Yang, L. Mandelco, and K. O. Stetter. 1990. The flexibacter-flavobacter connection. Syst. Appl. Microbiol. 13:161-165.

59. Wyffels, R., and J. Hommez. 1990. Pasteurella anatipestifer isolated from respiratory lesions in partridges kept in captivity (Perdix perdix). Vlaams Diergeneeskd. Tijdschr. 59:105-106. 